\title{
مقاصد اختلاف الدارين
}

\section{عبد الحكيم الصادق الفيتوري* ( م}

\section{المقدمة}

هذه الورقة قصد منها تقديم قراءة تأصيلية بحديدية أولية حول مفاهيم اختلاف الدارين، وأثر ذلك في اختلاف الأحكام، وكيفية الاستفادة من هذا الاختلاف بمعانيه الايجابية من حيث تطوير مفهوم المواطنة، وتسهيل عملية المعايشة، وتوطين فقه المسالمة بين المختلفين في الدين والدارين. كذلك ينبغي النظر إلى مفهوم اختلاف الدارين ودلالاته ومناطاته باعتبـاره مـن مسـائل الاجتهاد التي يجبـ مراعـاة عوامل كثيرة فيه، منها عوامـل البيئة السياسـية التي مـر بهـا منظـرو الفكـر الإسـلامي السياسي، مـن حـالات استضعاف ومراحـل استخلاف، ومدارج اجتهاد ونظر، ودركات تقليد وتخلف، وأثر ذلك في مصطلح اختلاف الدارين ومضامينه ودلالاته. وبهذا القدر من الوعي في الجانب التنظيري، ومراعاة المصطلح ومفاهيمه ومضامينه، واعتبار بيئات التحضر والتخلف - تصبح عملية صوابية إسقاط الدلالات على مناطاقا بقدر أكبر، والمسـاهمة في عملية الاستفادة من الإنتاج البشري والتقدم الحضاري أبلغ. تهـدف إلى بلـورة بجموعـة مـن المضـامين الجلديـدة لفلسففة اخـتلاف السدارين في إطـار اعتبـار تغيـير الإنسان والمكان والزمان، لتحقق الالتزام بقيم السماء، واحترام الإنسانية، والمحافظة على القيم العادلة، والآثار الصالحة في الواقع المعاصر بغية المساهمة في عملية توطين الإسلام ورفع معاناة المسلمين في الغرب. ولا شك أن الإضافة المعرفية التي أسفرت عنها هذه الورقة كانت في الجانب الفلسفي المقاصدي لعملية توطين الإسلام في غير دياره، وهذه الإضافة تحتاج إلى مناقشة وصقل، ولكن ما لا يدرك كله لا يترك جله. وقد حاولت الالتزام بروح مقاصد الرسالة الإسلامية من خلال كليات نصوص القرآن والسنة النبوية، مع مراجعة أقوال السلف في قضايا اختلاف الأحكام باختلاف الدار، وكنت أنتير مـ أقوالهم مـا يتفق مع المقاصد الكلية للقرآن ويناسب ظرف المسلم المقيم في الغرب دون إلزام نفسي بمذهب معين؛ إيمانا متِيّ بأنّ أقوالهم في دائرة الاجتهاد وليس في دائرة النص، كذلك فبإن جُلّ معالجتهم لقضايا الأقليـات -على قلتهاكانت تدور في حلقة ضيقة مفادها: إذا ما انفرد مسلم أو قافلة من دار الإسلام واخترقوا أراضي غير الإسلام

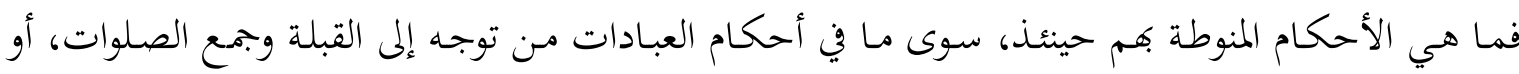
أحكام المعاملات من أنواع البيوعات الفاسدة والعقود الباطل ودفع المكوس وغير ذلك! 
وفي حسدود علمي أنه قد تعرض الفقه التقليدي في أمهات كتب السلف لجزئيات متنوعة تخص

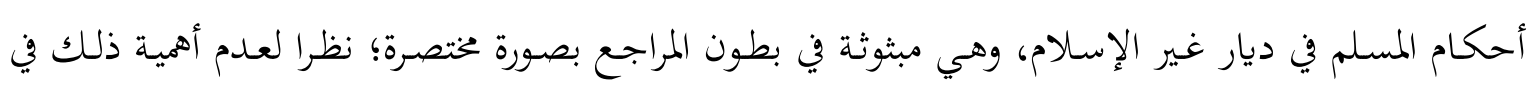

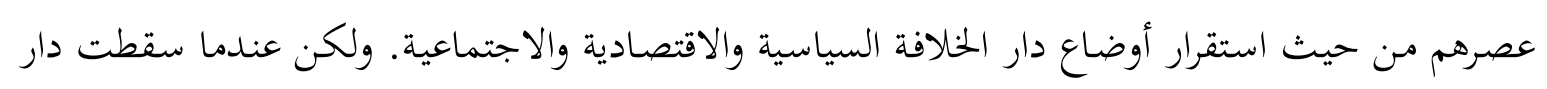

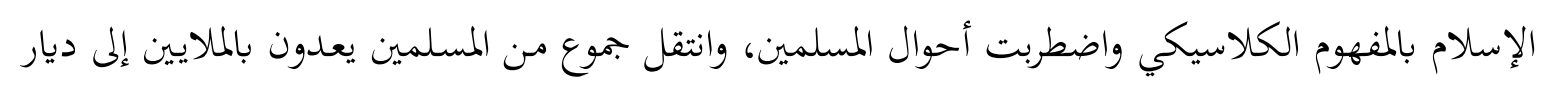

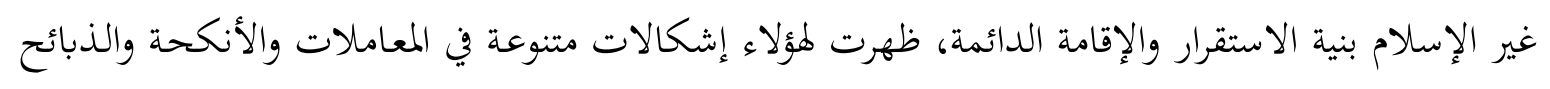

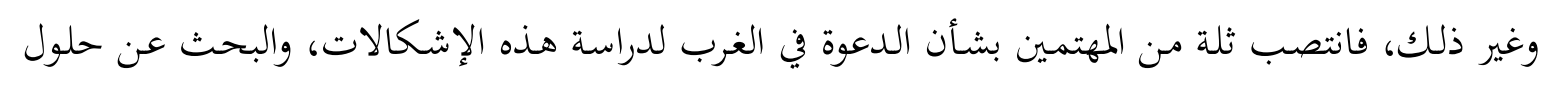

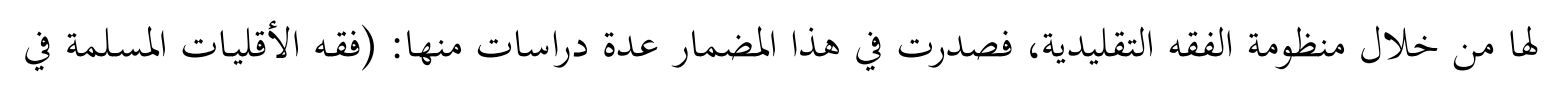

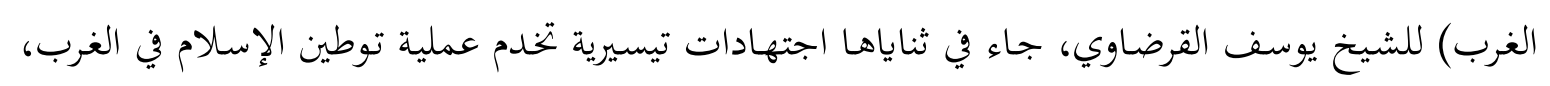

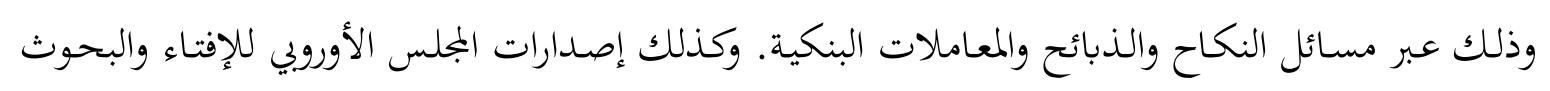

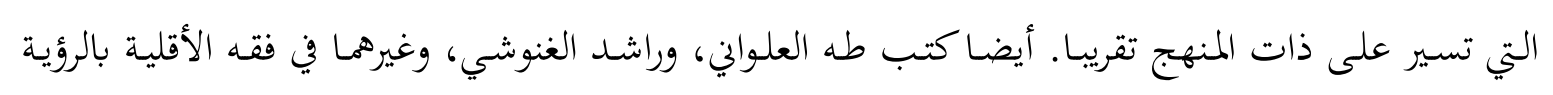
التجديدية.

وهناك رسالة دكتوراه تحت اسم: (اختلاف الدارين)، لإسماعيل فطاني، تناول فيها مسائل متفرقة في

فقه المناكحات والمعاملات المنوطة بالمسلم في غير دار الإسلام، ولكنها كانت بالطريقة التقليدية الكلاسيكية.

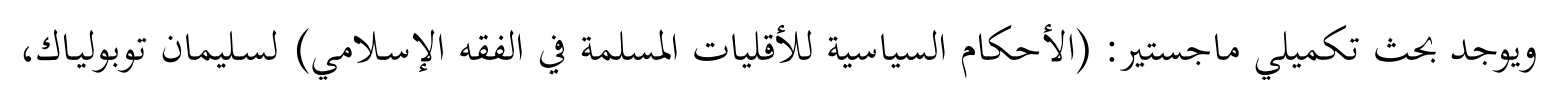

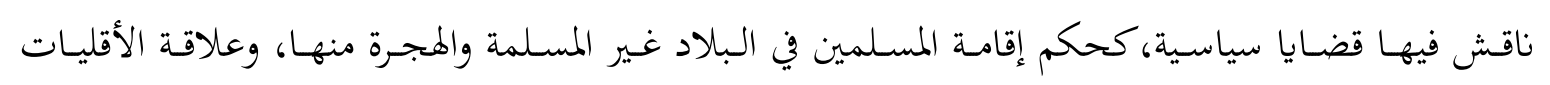

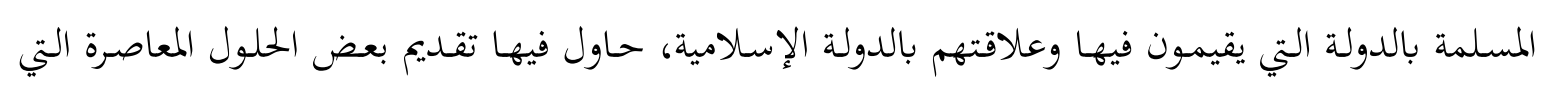
تخدم الجالية المسلمة.

\section{أولا: الدار، دلالاتما ومناط الحكم عليها}

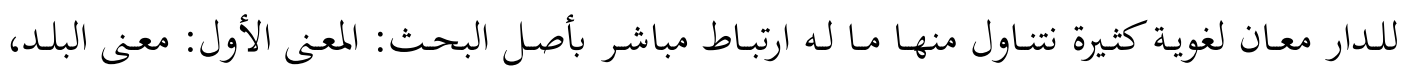

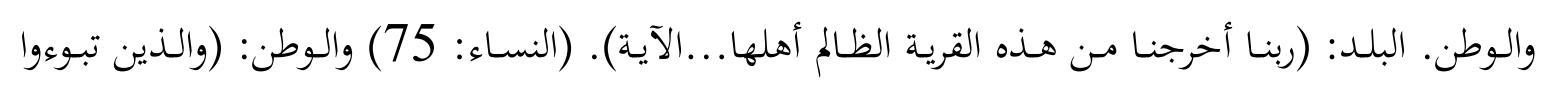

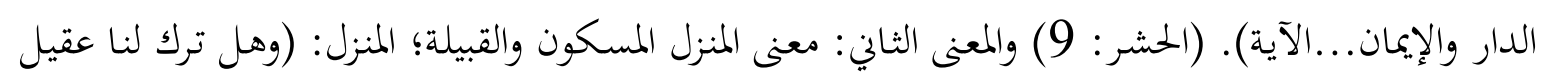

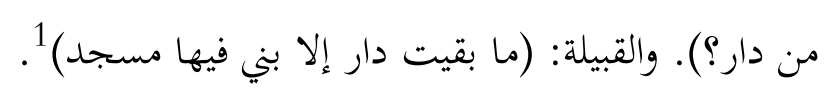

2 ابن منظور، أبو الفضل جمال الدين محمد أبو المكارم. لسان العرب، القاهرة: دار المعارف، 1981 ج4،

ص440-441. 
يقصد بالدار في كتب السياسة والعلاقات الدولية المعنى اللغوي الأول للدار (البلد والوطن)، التي

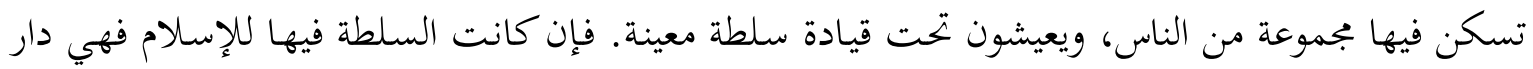

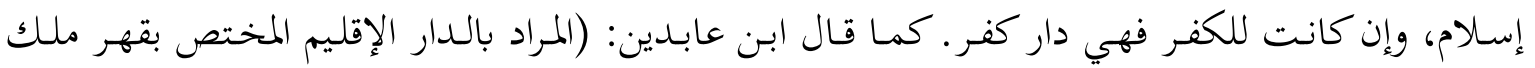

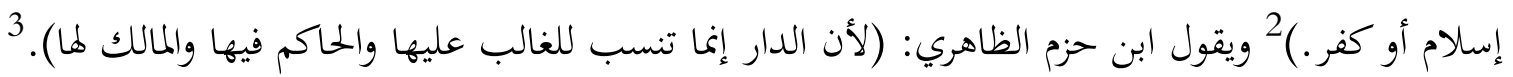
بناء على ذلك فإن معنى الدولة عند القانونين والدستورين المعاصرين متضمن لما جاء في معنى الدار

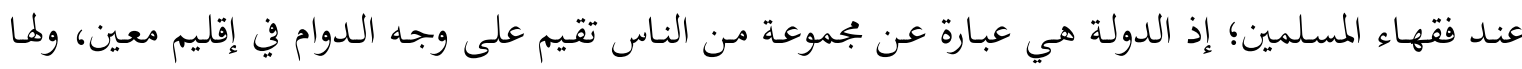
حاكم ونظام تخضع لمما، وشخصية معنوية واستقلال سياسي.4

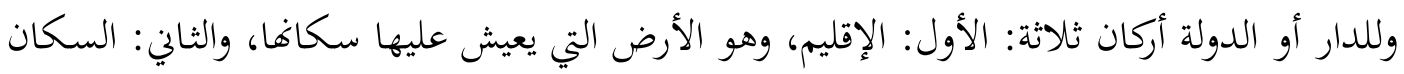

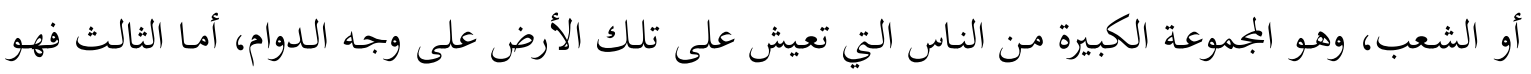

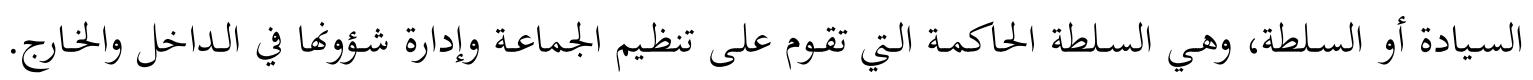
فالدار أو الدولة لا يقوم وجودها إلا بتوافر هذه الاركان الثلاثة.

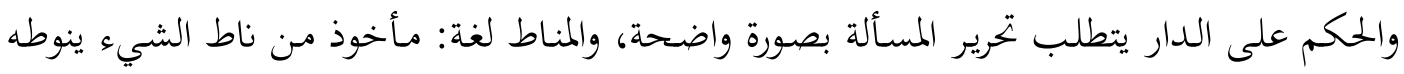

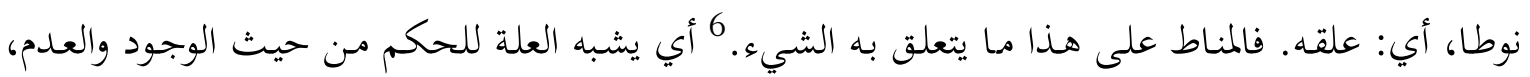

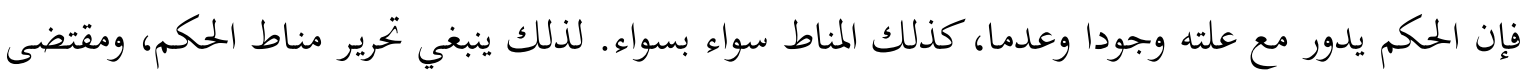

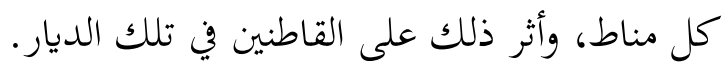
1. ت تحرير مناط الحكم على الدار:

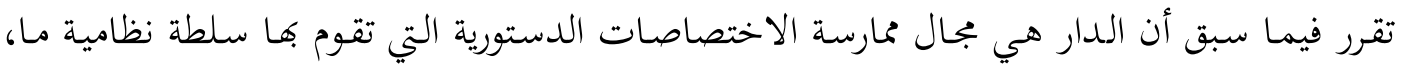

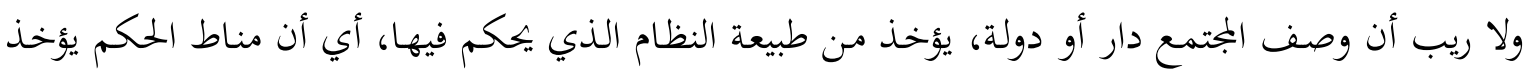

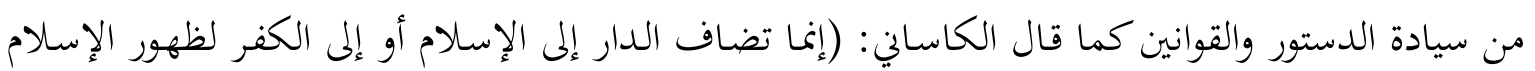

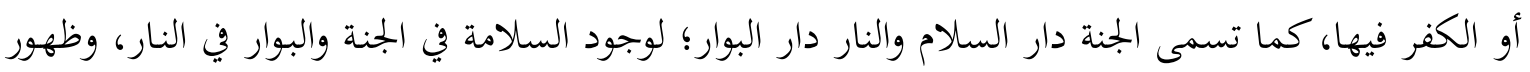

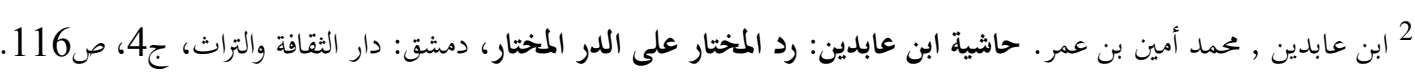

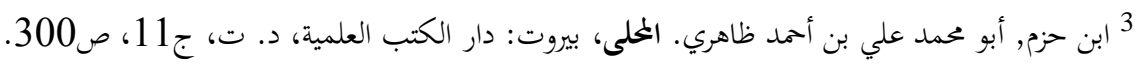

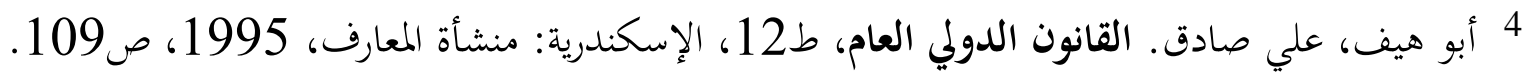

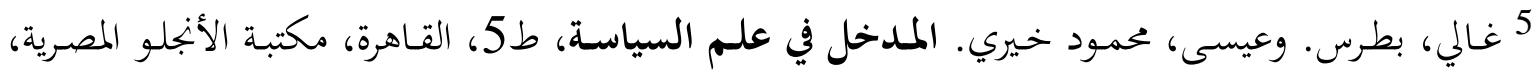

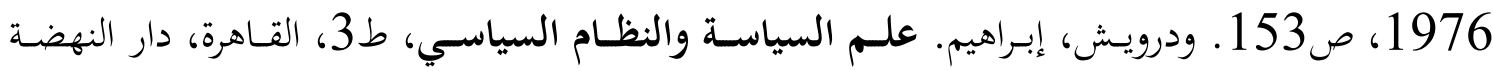

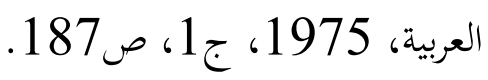

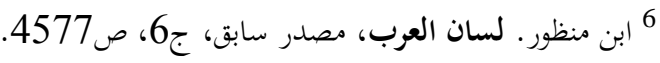


الإسلام والكفر بظهور أحكامهما، فإذا ظهرت أحكام الكفر في دار فقد صارت دار كفر فصحت الإضافة،

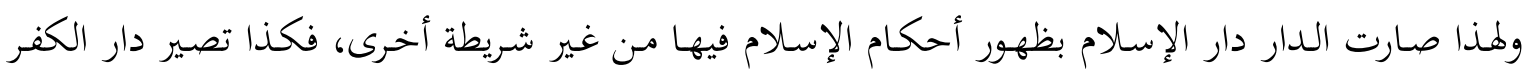

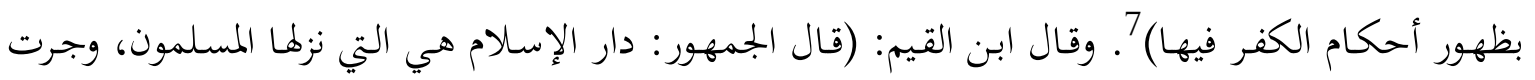

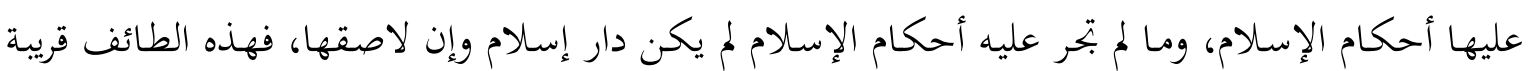

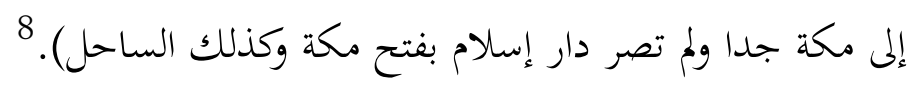

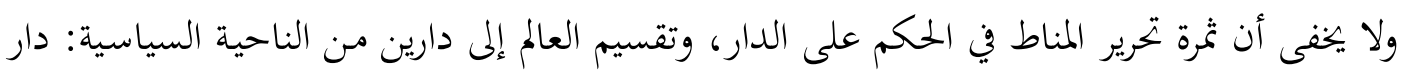

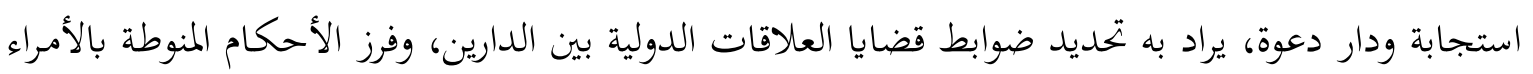

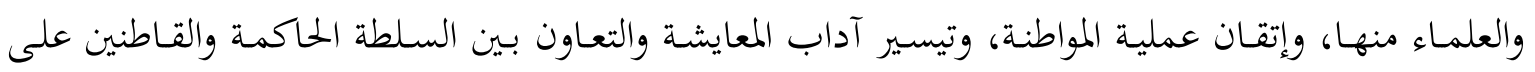
أرضها في الدارين، على الرغم من اختلاف المعتقدات والشرائع والديانات.

\section{2. تعريف دار الاستجابة:}

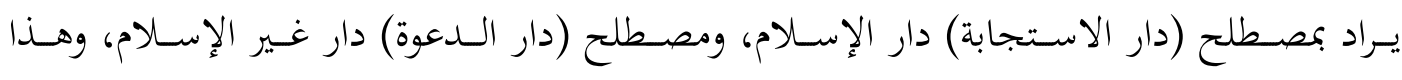

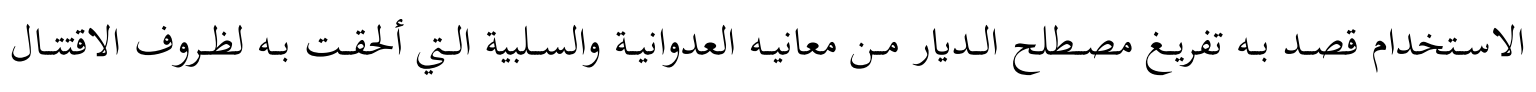

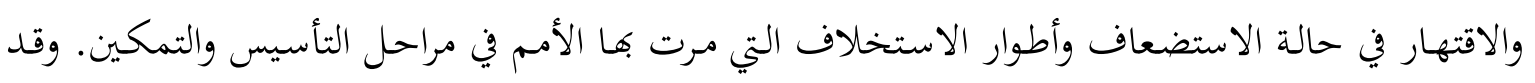

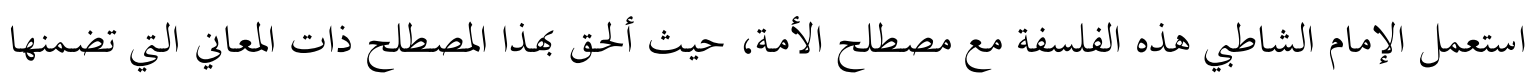

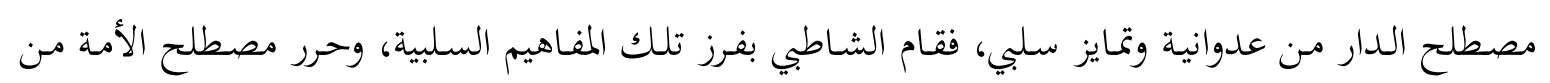

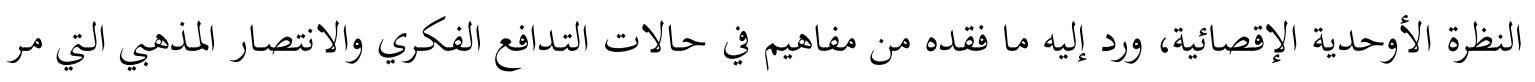
9 بها.

7 الكاساني، علاء الدين أبي بكر بن مسعود. بدائع الصنائع في ترتيب الشرائع، بيروت: دار إحياء التراث

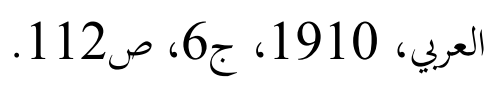

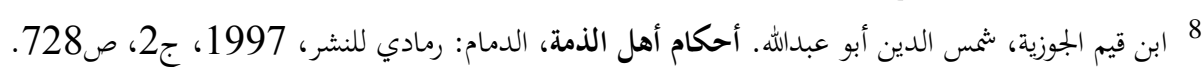

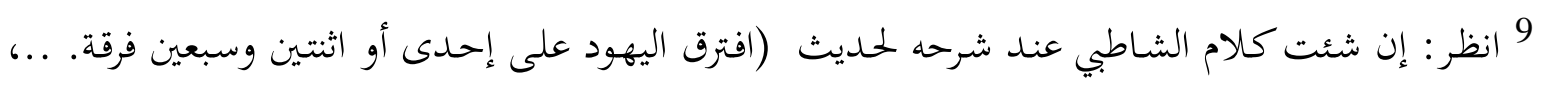

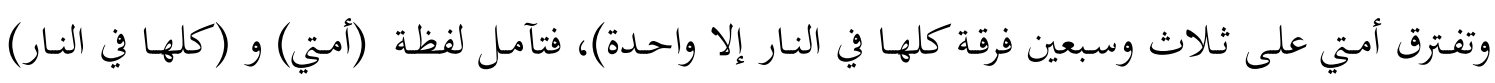

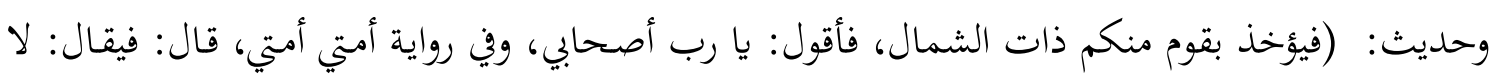

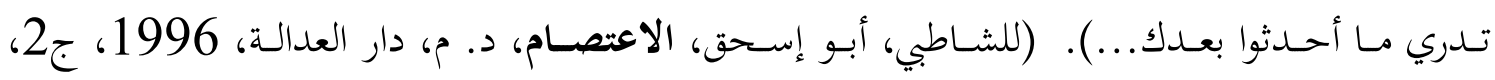

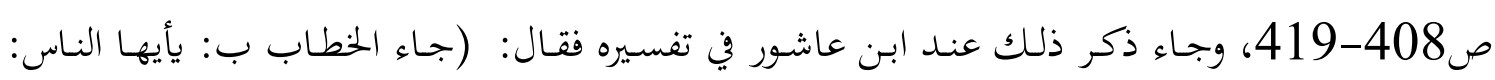

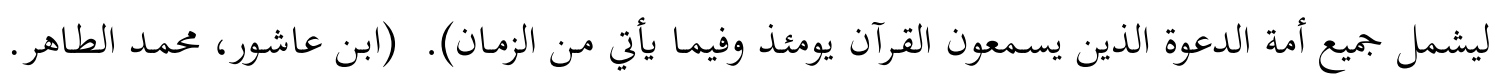


وعلى هـا الأسـاس نعرف دار الاستجابة بأهـا: الأرض التي تحكمها الشريعة الإلهية، وتكون المنعـة والشوكة فيها للمسلمين، كما قال عبد القاهر البغدادي: (كل دار ظهرت فيها دعوة الإسلام من أهلها بلا خفير ولا بجير ولا بذل جزية، ونفـذ فيها حكم المسلمين على أهل الذمة إن كان فيهم ذمي، ولم يقهر أهل البدعة فيها أهل السنة، فهي دار الإسلام، وإذا كان الأمر على ضد ما ذكرناه في الدار فهي دار الكفر). 10 وعرفها عبد الرحمن السعدي بقوله: (فبلاد الإسلام: التي يككمها المسلمون، وتجرى فيها الأحكام الإسلامية، ويكون النفوذ فيها للمسلمين، ولو كان جمهور أهلها كفارا، وبلاد الكفر ضدها). 11 وأكد سيد

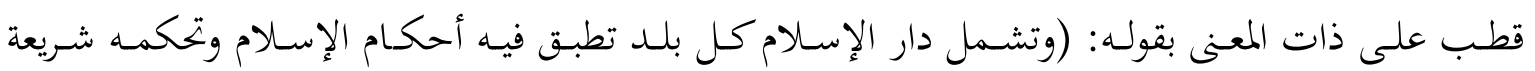

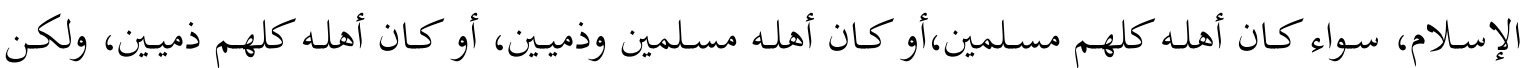
حكامه مسلمون يطبقون فيه أحكام الإسلام، ويمكمونه بشريعة الإسلام). 12 3. تعريف دار الدعوة: وتسمى دار الموادعة، ودار الصلح، ودار المعاهدة، ودار الهدنة، ودار الذمة، ودار الكفر ... وهي كل ناحية صالح المسلمون أهلها بترك القتال على أن تكون الأرض لأهلها، أو تصالحوا على قيم سياسية سلمية تضبط علاقة كل منهما بالآخر، مع رفضهم الإسلام وأحكامه، أو لعدم ولاية إمام المسلمين عليها. لذلك يمكن تعريفها بأهـا: كل بقعة تكون فيها أحكام الكفر ظاهرة، سواء كان بينهم وبين إمـام المسلمين عهد، أو صلح، أو لم يكن بينهم شيء مـن ذلك. يقول ابن القيم رحمه الله: (قال الجمهـور : دار

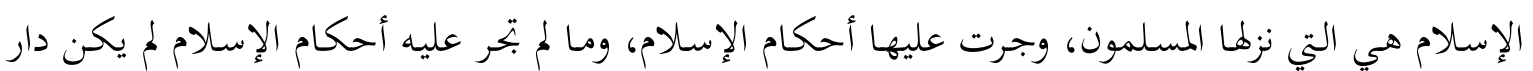
إسلام وإن لاصقها، فهذه الطائف قريبة إلى مكة جدا ولم تصر دار إسلام بفتح مكة، وكذلك الساحل). 13 وقال أبو يوسف: (تعتبر الدار دار كفر بظهور أحكام الكفر فيها وإن كان جل أهلها من المسلمين). 14

التحريسر والتنـوير، بـيروت: مؤسسـة التـاريخ، 2000، ج4، ص8) واستعمل هـذا المصطلح جمهرة مـن الدعاة المعاصرين منهم: القرضاوي، العلواني، البوطي.

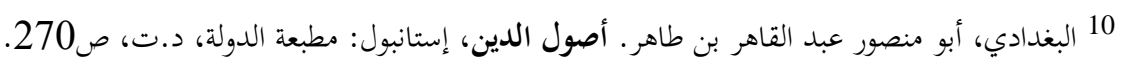

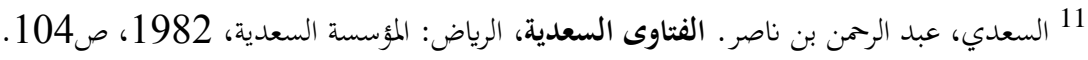

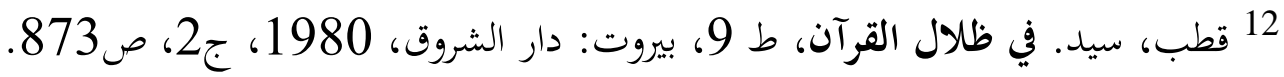

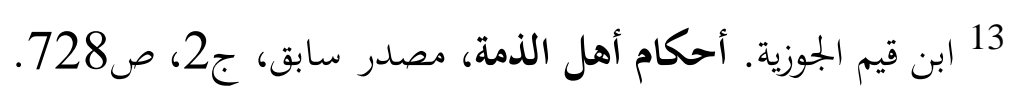

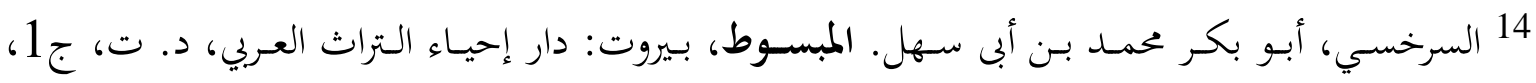
ص220. 
وبجمل القول في تحرير مناط الحكم على الدار منوط بغلبة الأحكام، المتمثلة في قوة هيمنة الأحكام

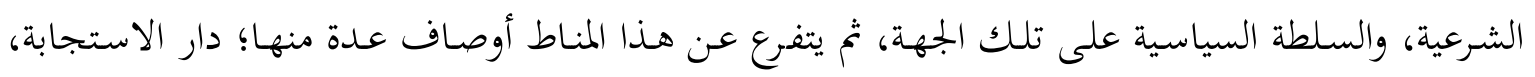

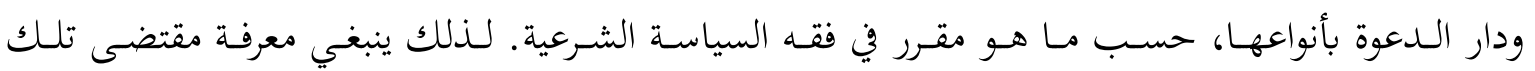
الأوصاف والمناطات، وما يترتب عليها من التزامات وغير ذلك.

4. مقتضى دار الاستجابة: الأصل في الناس فيها الإسلام، وتطبيق أحكام الشريعة واجبة على على دانى

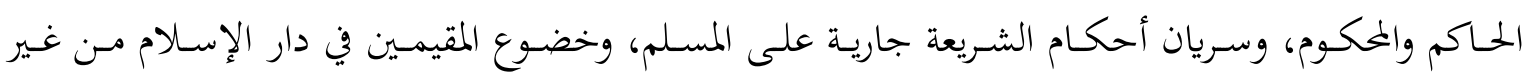

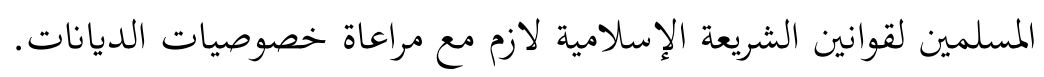

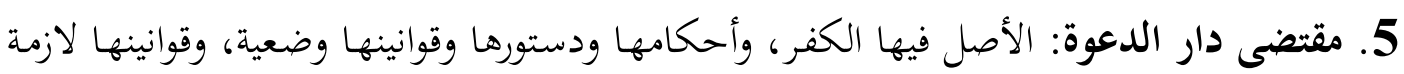

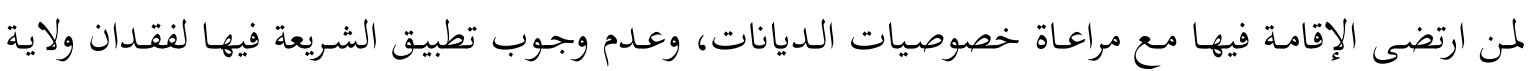
سلطان الإسلام عليها.

\section{ثانيا: أصالة تقسيم الدور:}

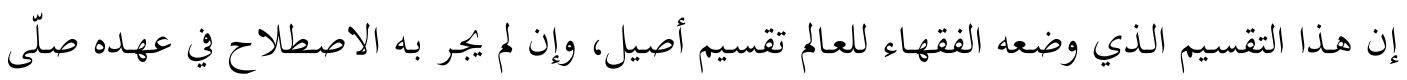

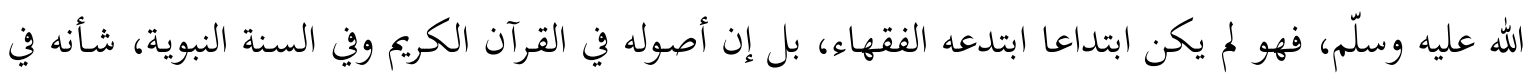
ذلك شأن كثير من التقسيمات في الفقه الإسلامي.

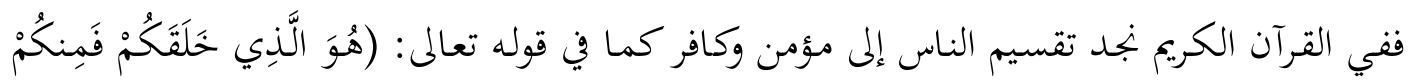

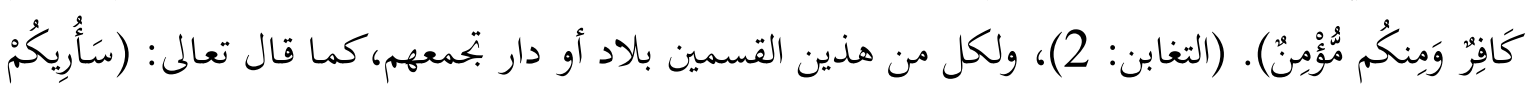

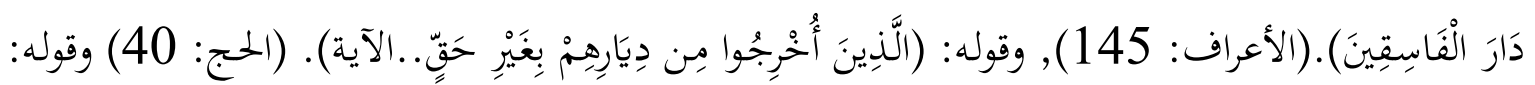

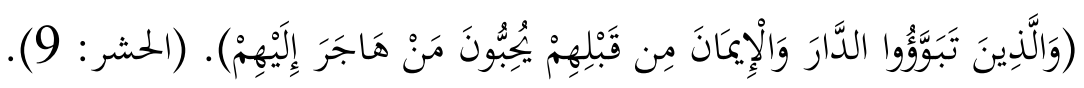

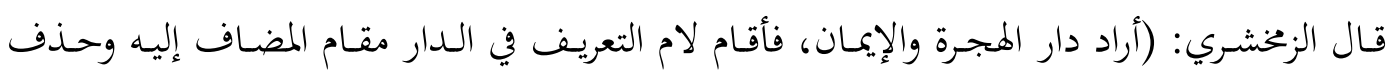

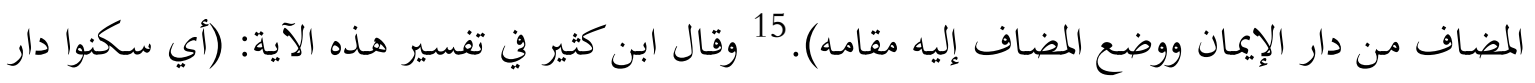
الهجرة من قبل المهاجرين وآمنوا قبل كثير منهم). 16

15 الزيخشري، أبو القاسم جـار الله. تفسير الكثـاف عـن حقـائق التنزيل وعيون الأقاويـل، بيروت: دار

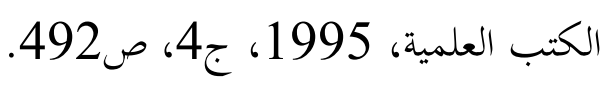

16 ابن كثير، عماد الدين أبو الفداء إسماعيل. تفسير القرآن العظيم، المدينة المنورة: مكتبة العلوم والحكمة،

1993، ج4، ص337. 
وفي السنة النبوية وفي الآثار عن الصحابة جاء هذا المعنى واضحا باسم دار الشرك، ودار السنة، ودار

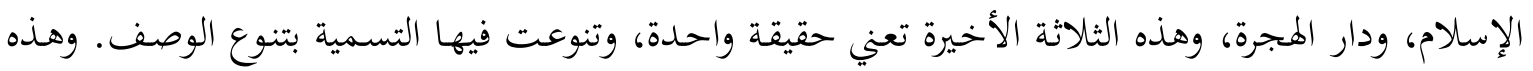

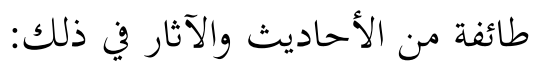
- روى النسائي في سننه عن جابر بن زيد قال: قال ابن عباس: (أن رسول الله صلّى الله عليه وسلّم

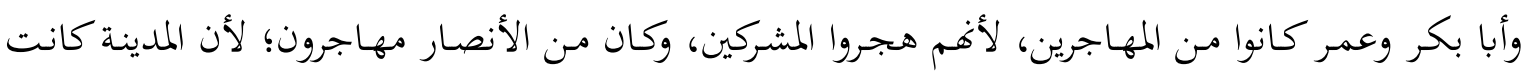
دار شرك، فجاءوا إلى رسول الله صلّى الله عليه وسلّم ليلة العقبة). - وروى الإمام مسلم في صحيحه عن بريدة قال: (كان رسول الله صلّى الله عليه وسلّم إذا أمر أميرا

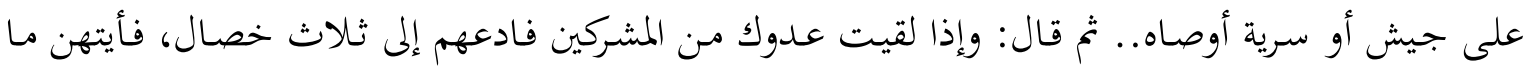

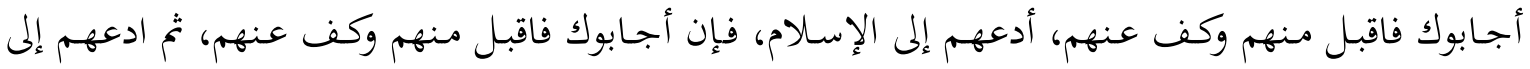
التحول من دارهم إلى دار المهاجرين). فالدار الأولى هي دار المشركين، والثانية هي دار المهاجرين وهي دار الإسلام، المام، التي جاءت في رواية

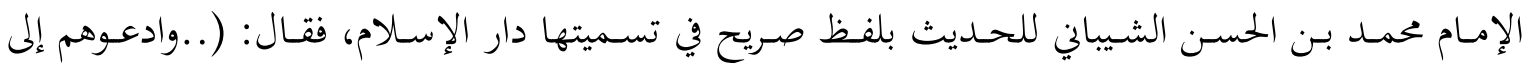
التحول إلى دار الإسلام).

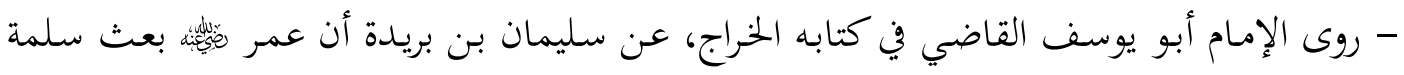

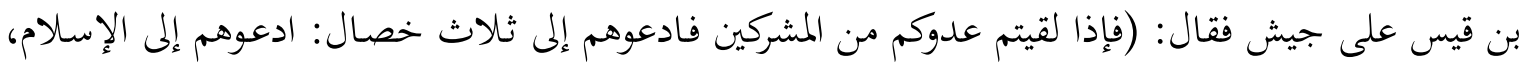
فإن أسلموا فاختاروا دارهم فعليهم في أمواهم الزكاة).

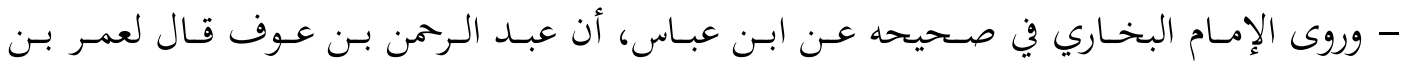

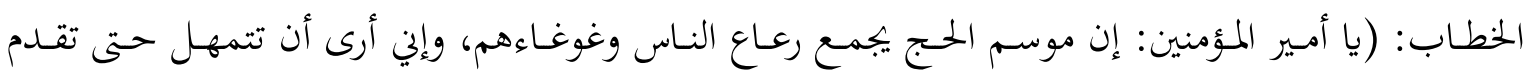
المدينة، فإنها دار المجرة والسنة). - وجاء في كتاب خالد بن الوليد لأهل الحيرة: (وجعلت لهم أيما شيخ ضعف عن عن العمل أو أصابته

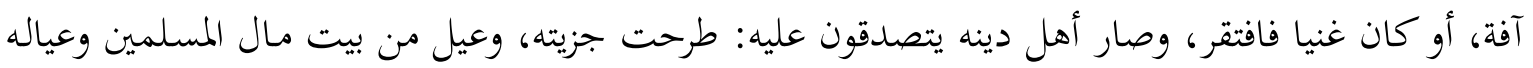

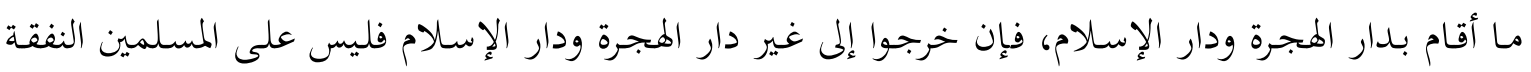
على عيالمم). ففي هذه الأحاديث والآثار وفي غيرها أيضا جاء اسم (دار الهجرة) و(دار الإسلام) و(دار السنة)

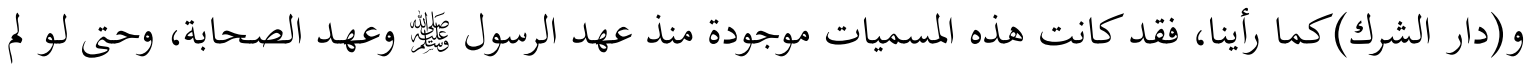

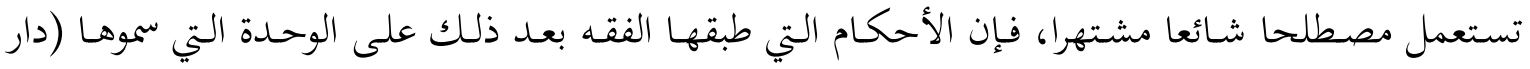

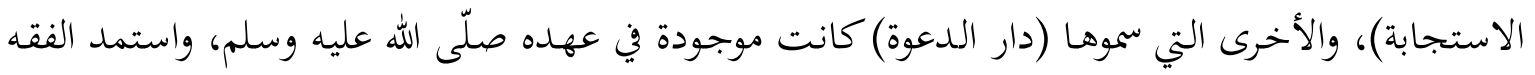


منها تقنينه لما أطلق عليه كل من الاسمين، فلا دلالة إذن للقول بأن هذه التسمية طارئة مستحدثة، ولا سند للقول بعدم شرعية تقسيم العالم إلى دارين؛ دار استجابة، ودار دعوة.

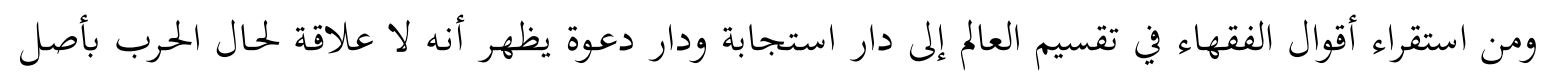

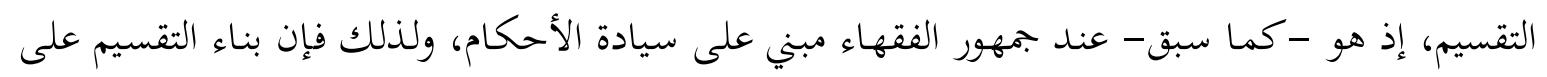

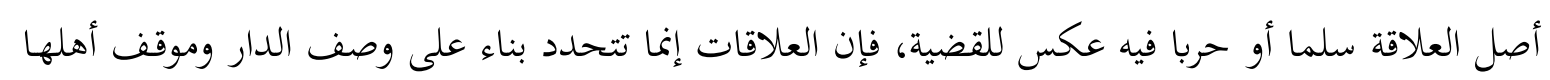

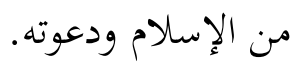

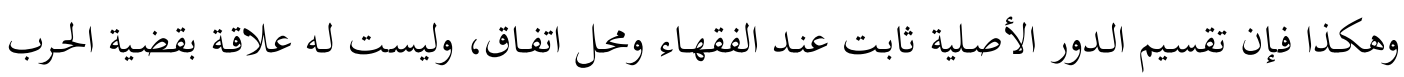

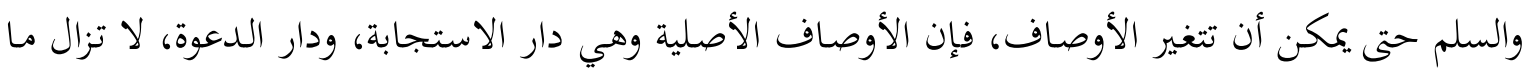

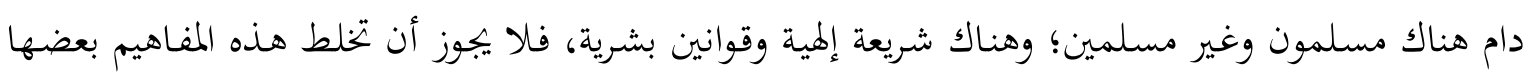

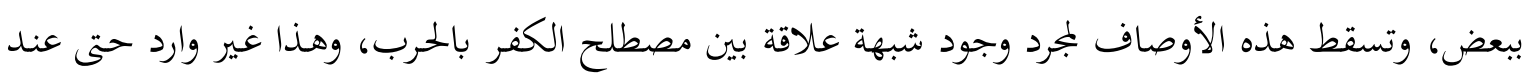

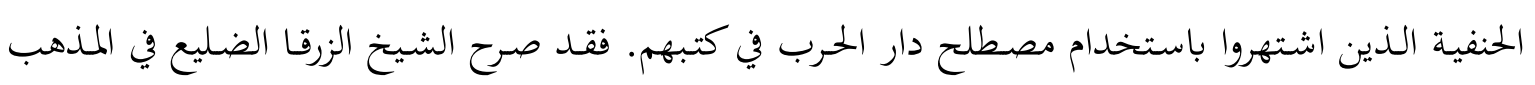

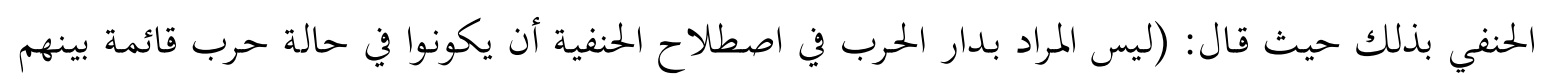

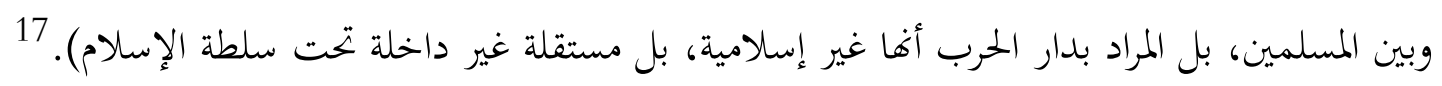

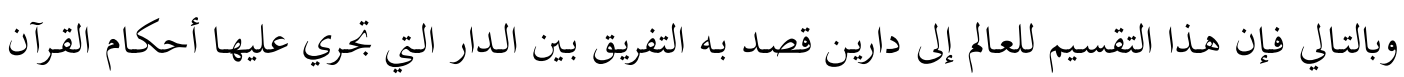

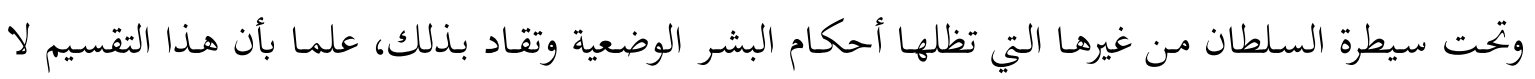

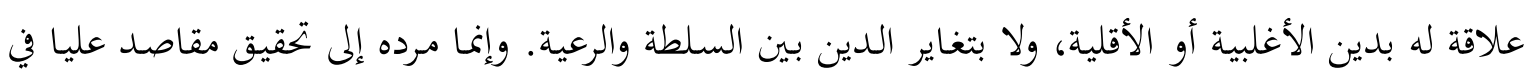

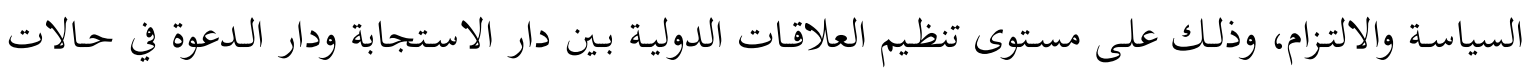

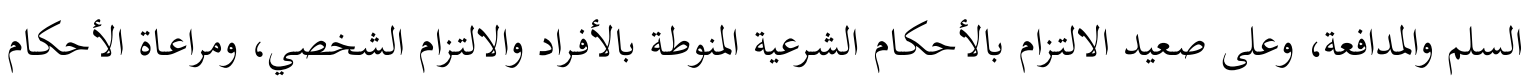

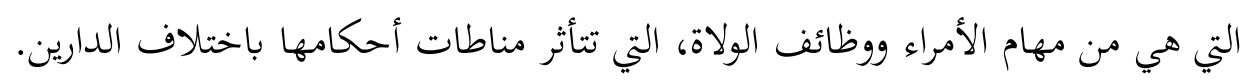

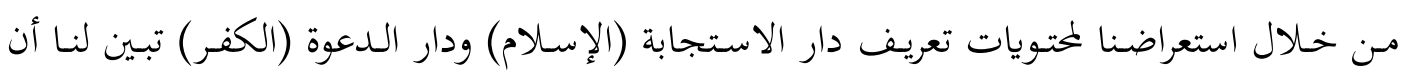

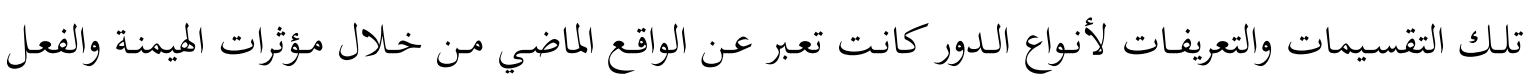

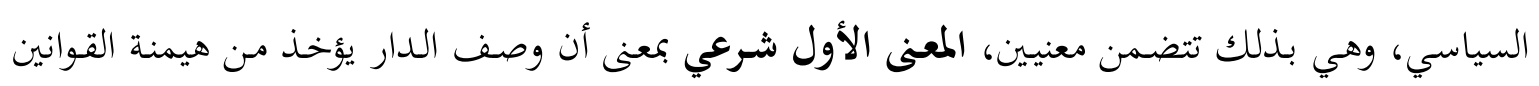

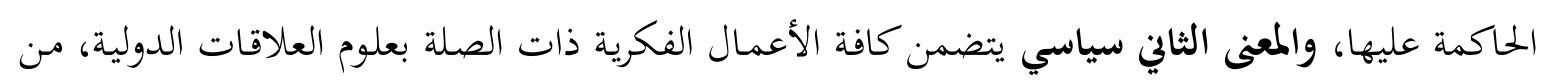

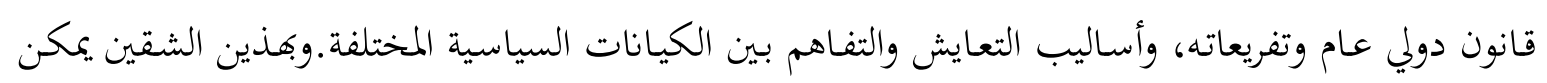

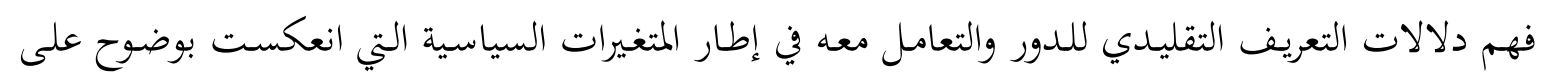

17 الزرقا، مصطفى. فتاوى مصطفى الزرقا، ط3، دمشق: دار القلم، 2003، ص626. 
ساحة التنظير السياسي، فبينما كان مركز التنظير فيما مضى دار الخلافة الإسلامية (بغداد-دمشق) أضحت

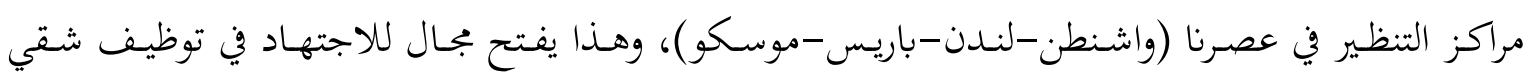

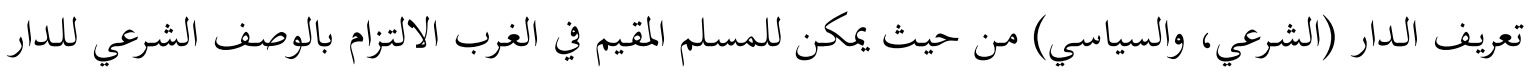

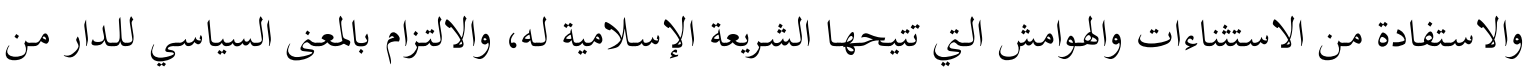

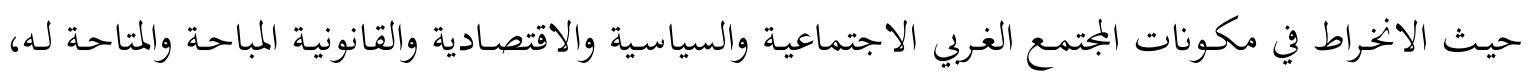
وبذلك يصير المسلم مسلما ملتزما بدينه ومواطنا صالحا لوطنه الجلديد.

ثالثا: الأبعاد الفلسفية لاختلاف الدارين:

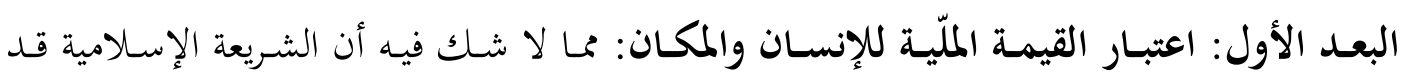

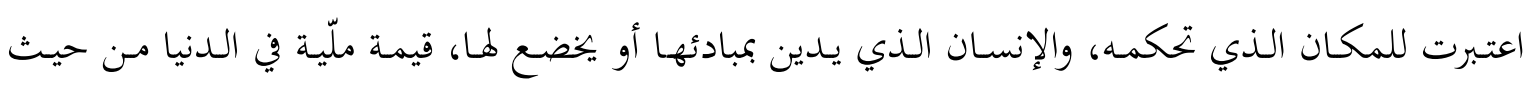

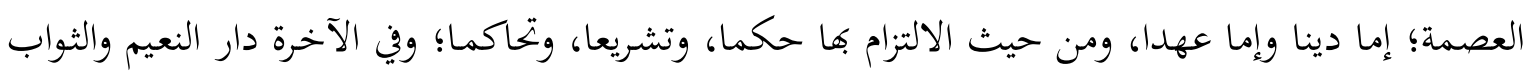

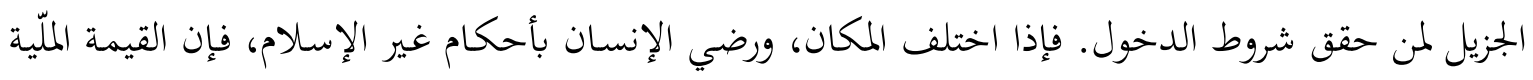

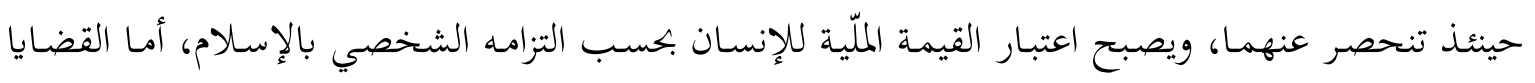

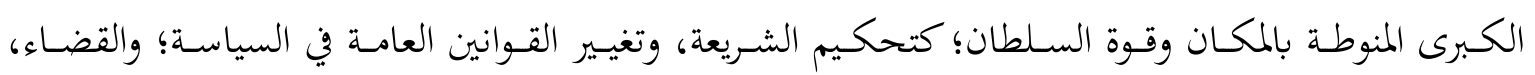

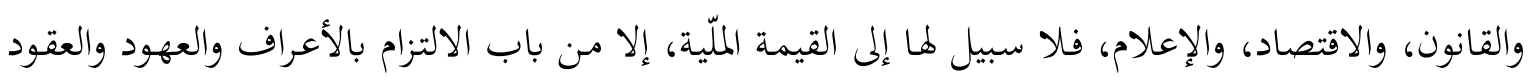
والمواثيق السائدة في ذلك المكان.

لذلك يمكن القول بأنه لا علاقة لاعتبار القيمة الملية للمكان والإنسان بحالة الحرب والسلم، ولا بحالة

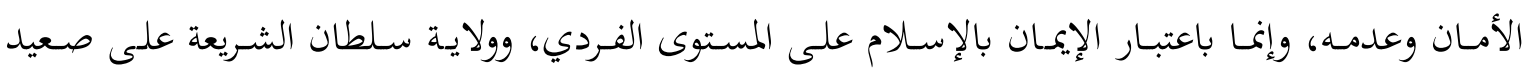

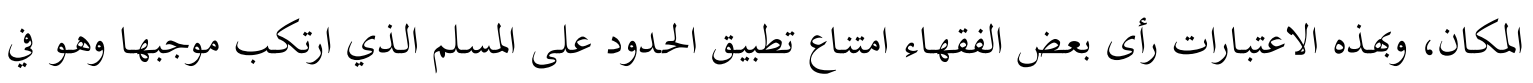

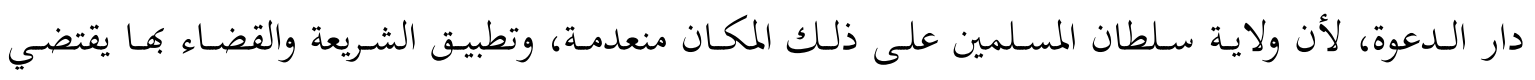

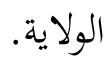

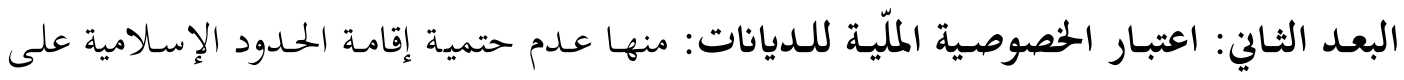

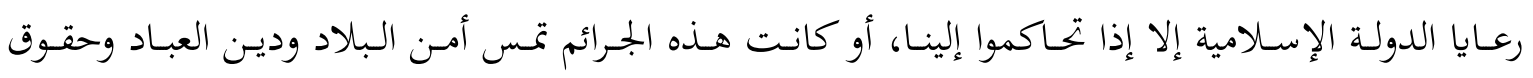

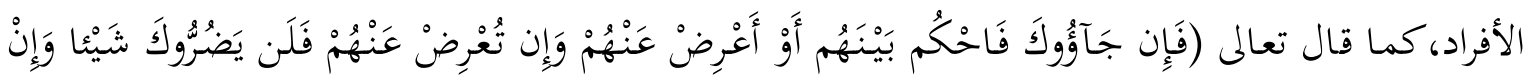

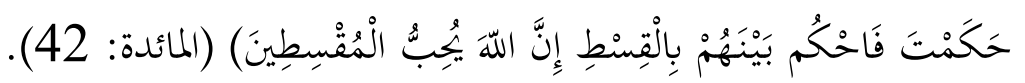

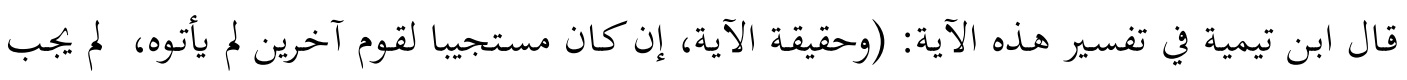

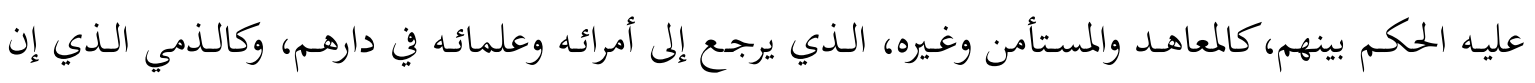


حكم له بما يوافق غرضه وإلا رجع إلى أكابرهم وعلمائهم، فيكون متخيرا بين الطاعة لحكم الله ورسوله، وبين

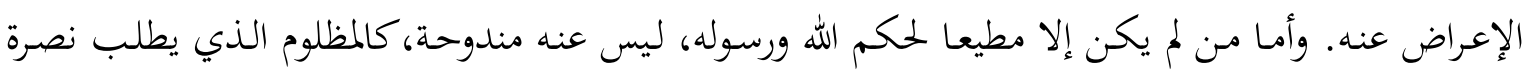

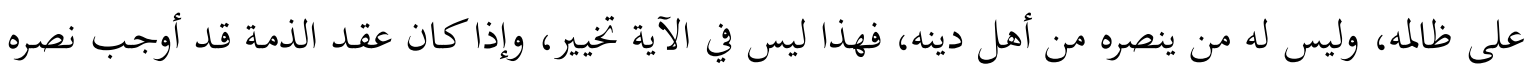

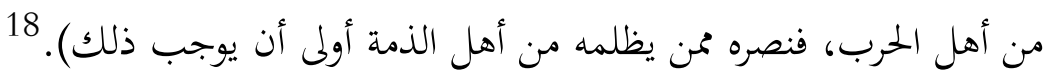

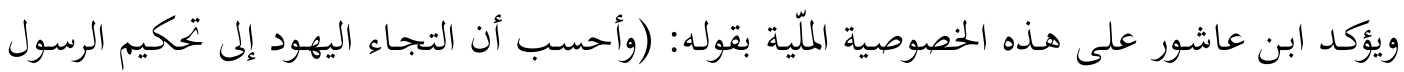

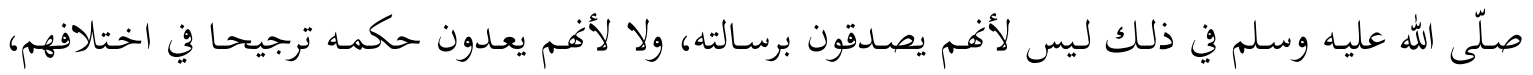

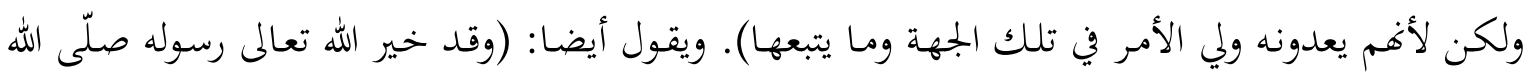

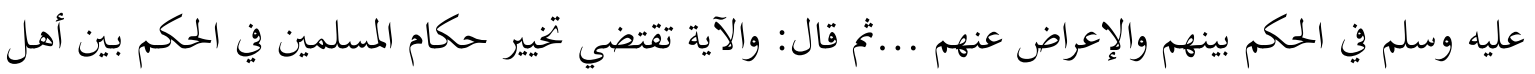
الكتاب إذا حكموهم؛ لأن إباحة ذلك التخيير لغير الرسول من الحكام مساو إباحته للرسول). ويقول في

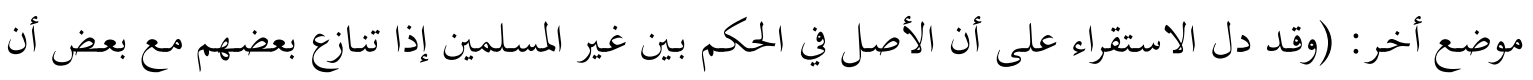

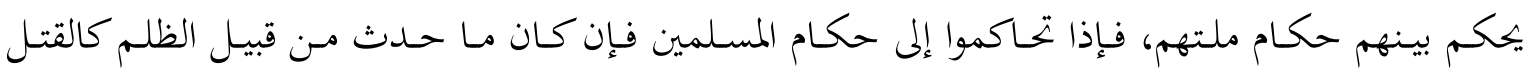

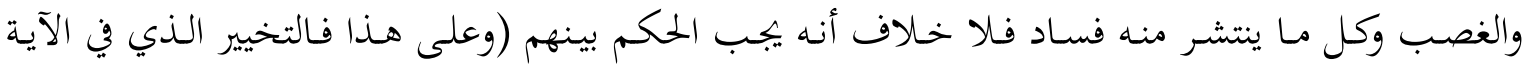
خخصوص بالإجماع) وإن لم يكن كذلك كالنزاع في الطلاق والمعاملات). 19

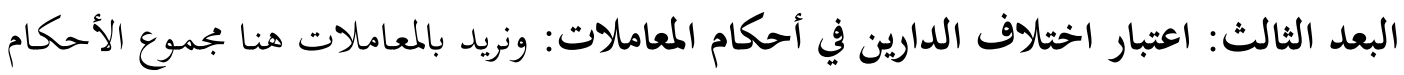

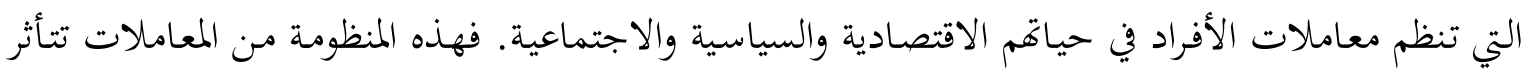

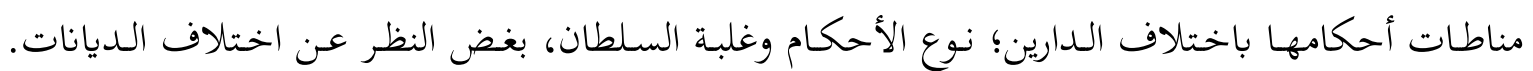
وفيما يأتي بيان ذلك في عدد من الأمثلة:

\section{التعاملات الربوية والعقود الفاسدة:}

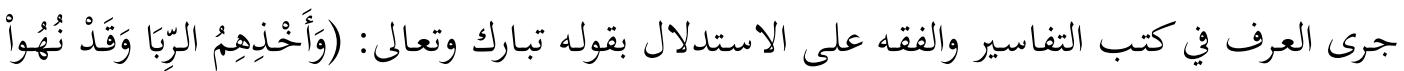
عَنْهُ). (النساء: 161) بأنه دليل على حرمة التعامل بالربا بين بني اسرائيل وغيرهم، وأن الكفـار مخاطبون

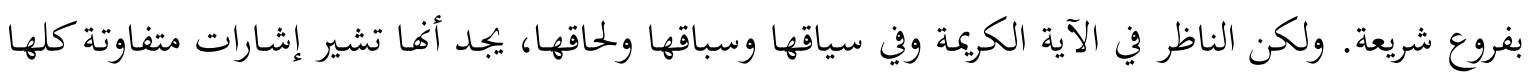

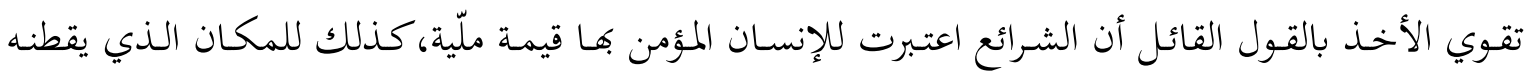
وتظله أحكام السماء فيه، من حيث سريان الأحكام، وولاية السلطان.

18 ابن تيمية، تقي الدين أحمد بن عبدالحليم. مجموع الفتـاوى، القاهرة: مكتبة الوفاء، 1997، ج28، 


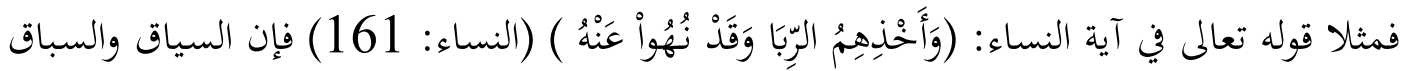

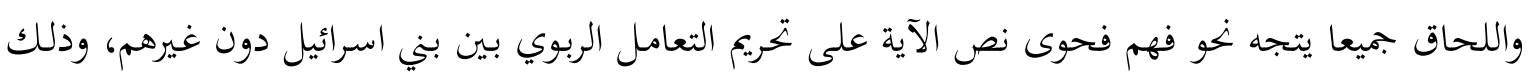

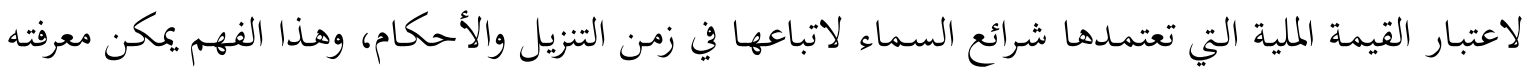

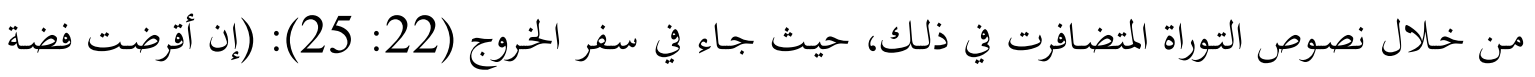

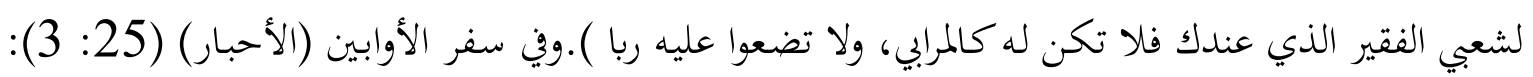

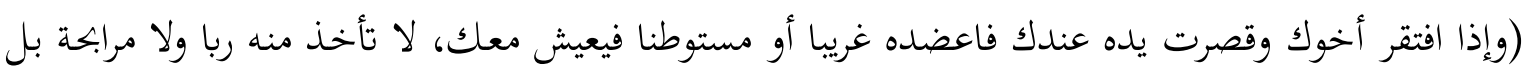

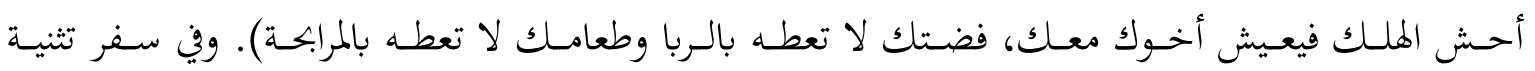

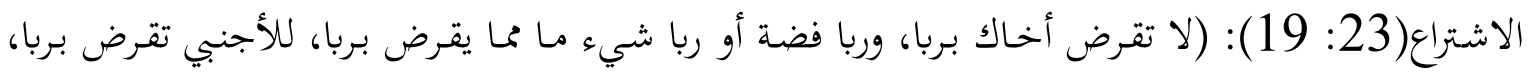
ولكن لأخيك لا تقرض بربا). وهذا الفهم قدمه ابن عاشور في تفسير آية النساء (وأخذهم الربا وقد نهوا عنه) والذي يجدر سرده في

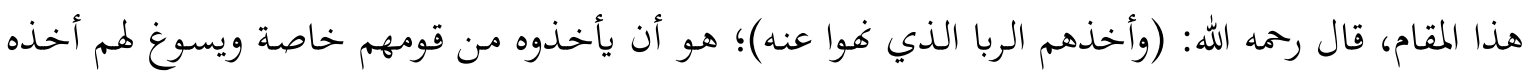

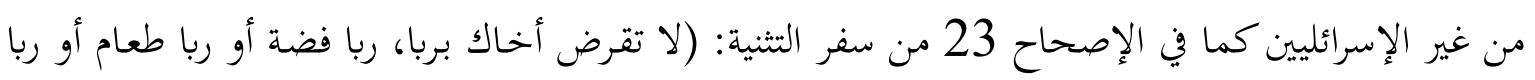

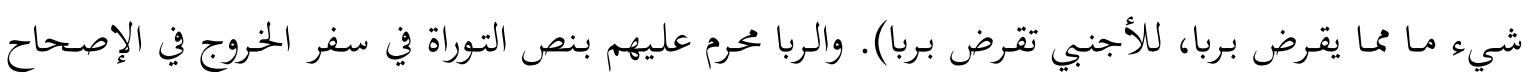

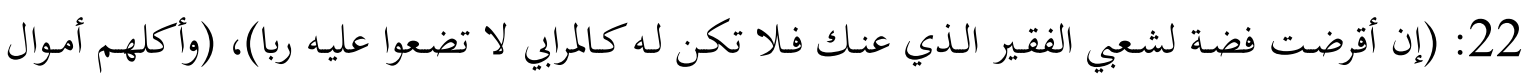

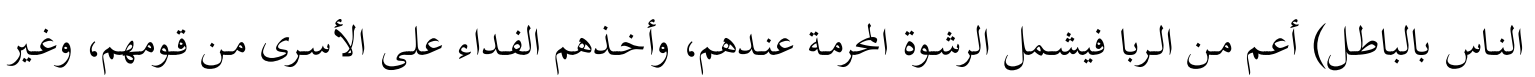
ذلك).

ويشكل على بعض الفضلاء حالة التوفيق والتوجيه بين قوله تعالى: (وأخذهم الربا الذي غوا عنه)

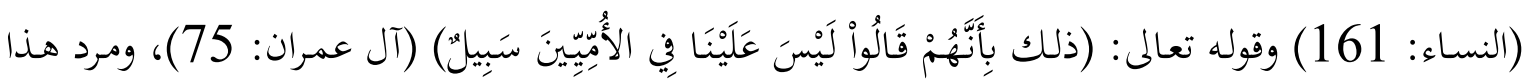

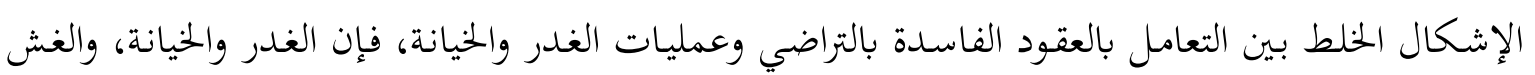

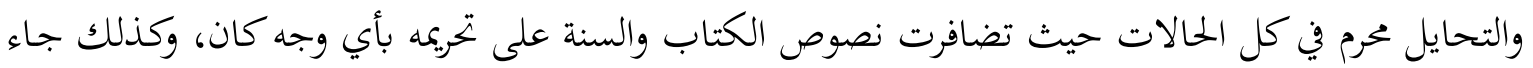

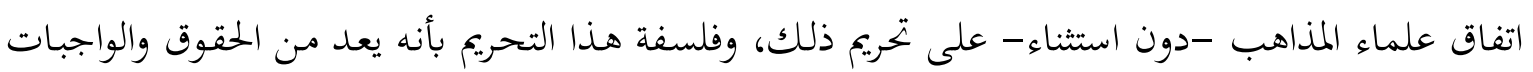

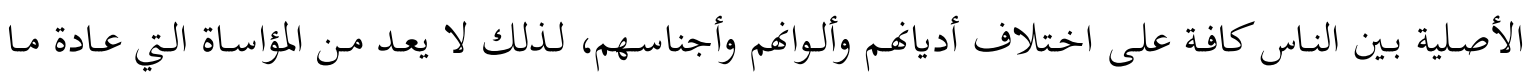

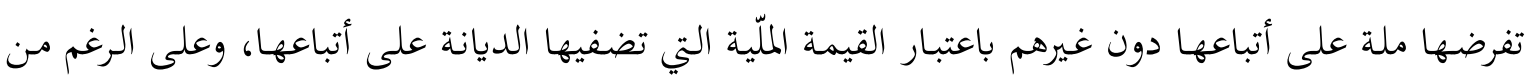

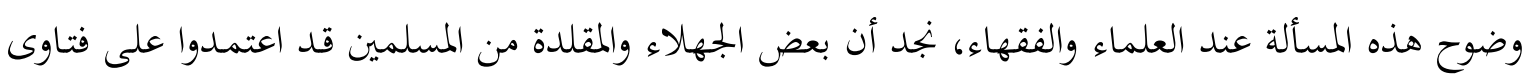

ابن عاشور . التحرير والثنوير، مصدر سابق، ج4، ص311-312. 
بعض الفقهاء الذين أجازوا التعامل بالعقود الفاسدة كالربا والبيوعات الفاسدة في غير دار الإسلام، وجعلوا

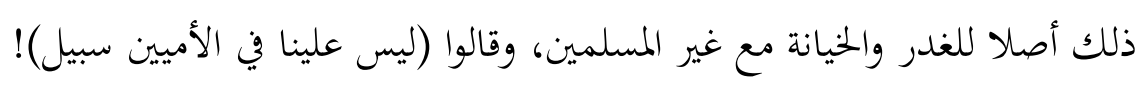

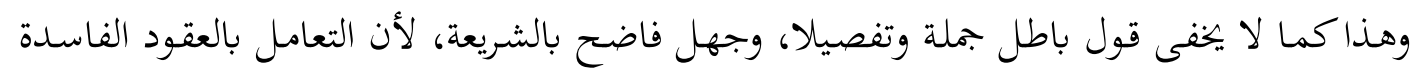

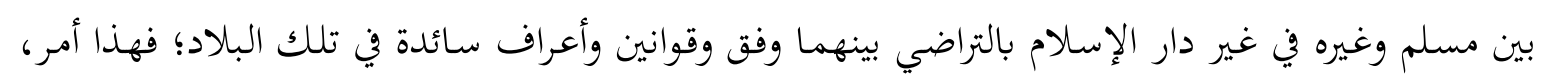

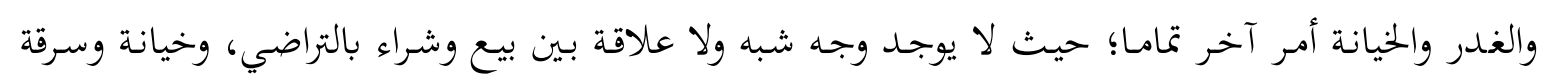

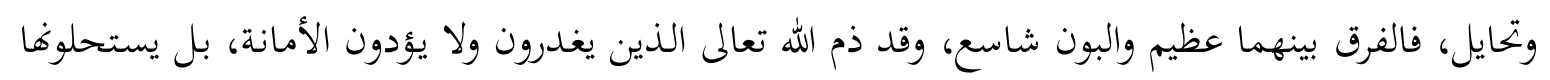

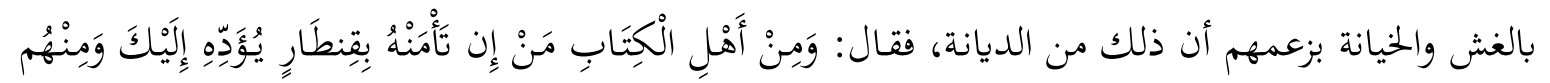

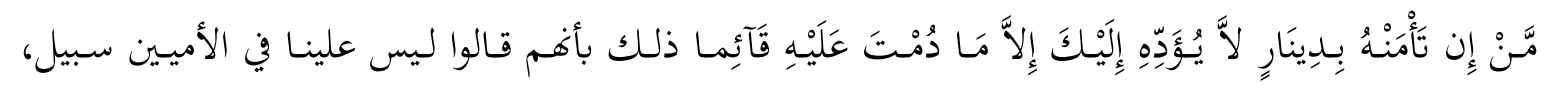

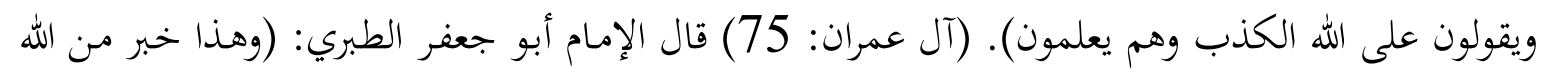

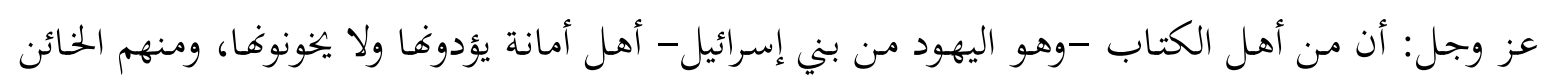
أمانته، الفاجر في يمينه، المستحل).

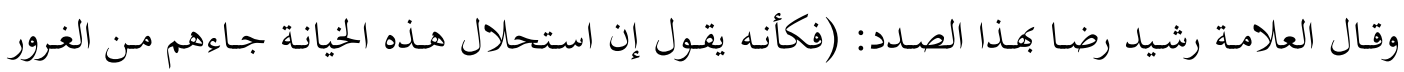

بشعبهم والغلو في دينهم، فإن ذلك يستتبع احتقار المخلف احتقارا يهضم به حقه الثابت في المعاملة). 22

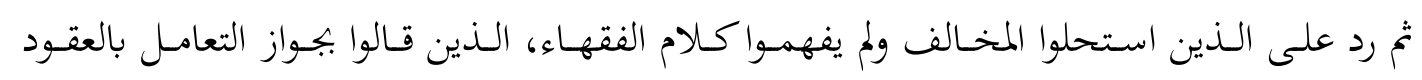

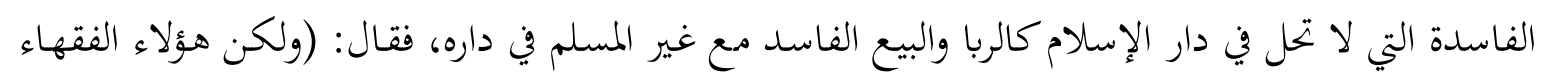

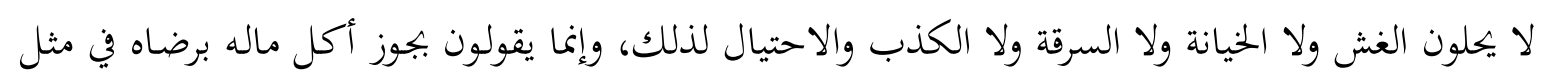

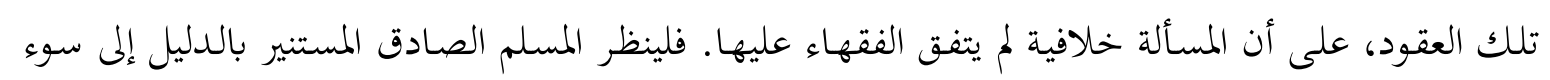

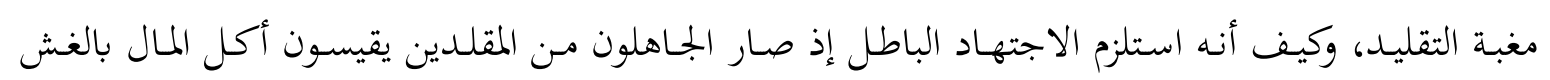
والخيانة والسرقة على أكله بالعقود الفاسدة مع التراضي، وبينهما فرق عظيم). 23

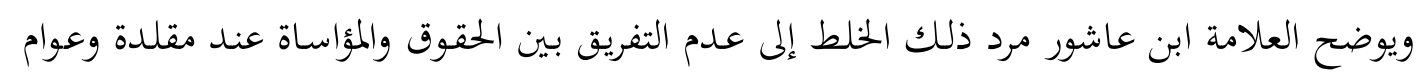

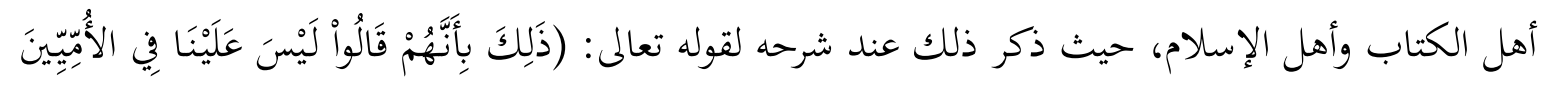

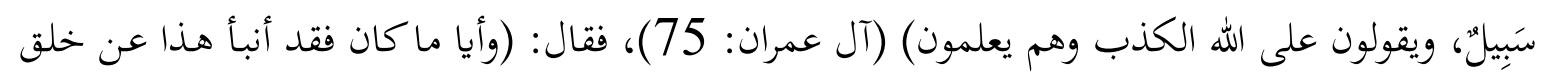

21 الطبري، أبو جعفر محمد بن جرير. جامع البيان في تأويل القرآن، القاهرة: دار المعارف، 1971، ج3، ص.315.

$$
22 \text { رضا، محمد رشيد. تفسير المنار، القاهرة: دار المنار، 1954، 1975، ج3، ص297، ص296. }
$$




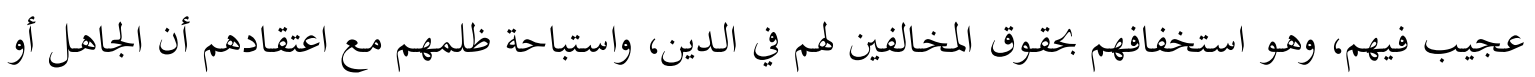

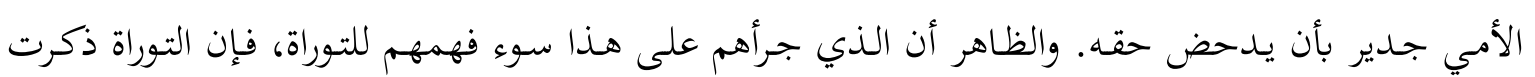

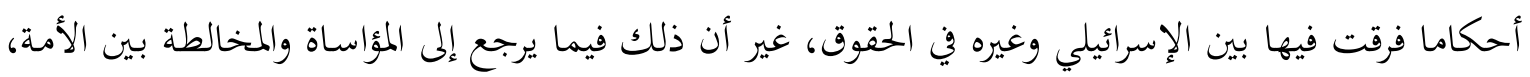

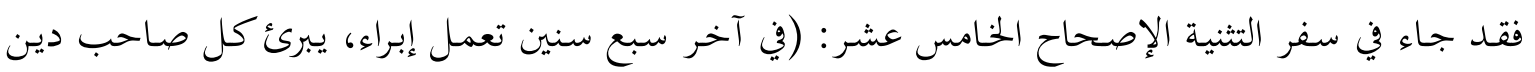

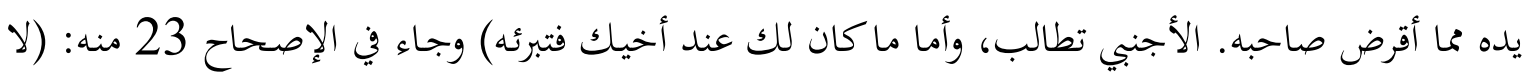

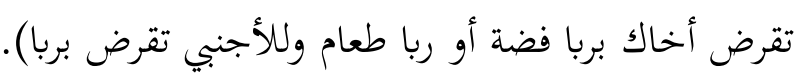
ولكن شتان بين الحقوق وبين المؤاساة؛ فإن تحريم الربا إنما كان لقصد المانيا).

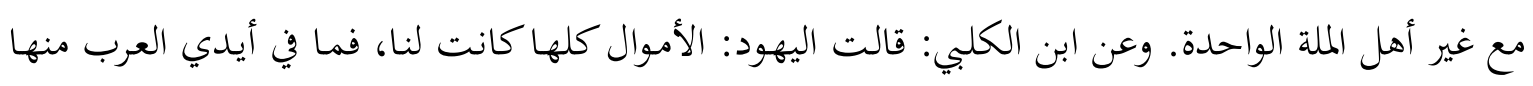

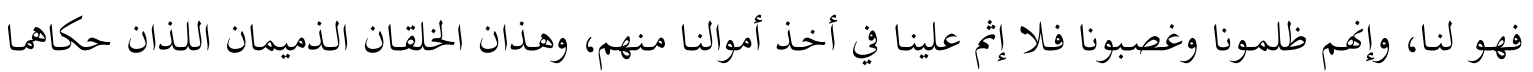

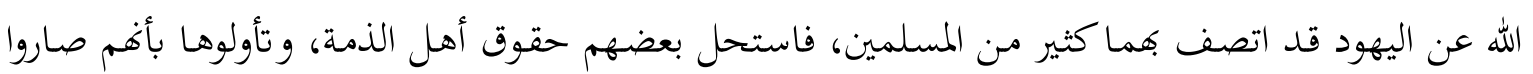

$$
\text { أهل حرب، في حين لا حرب ولا ضرب.) }
$$

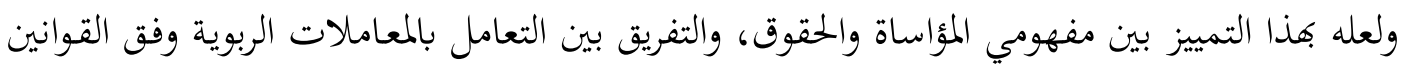

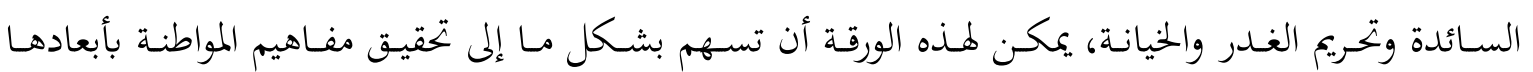

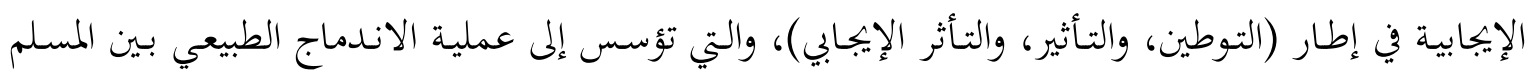

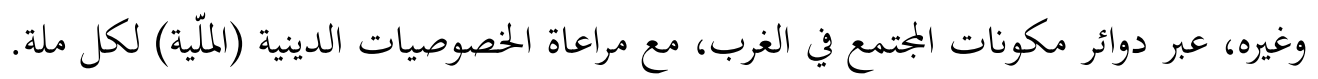

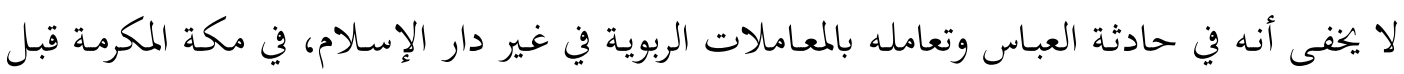

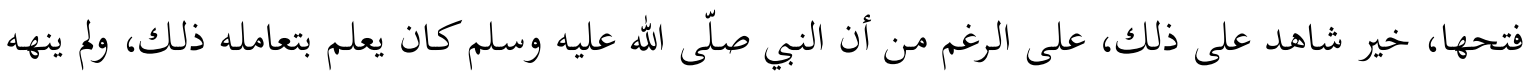

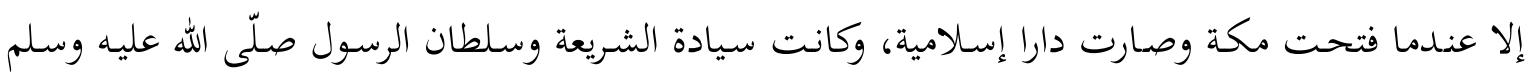

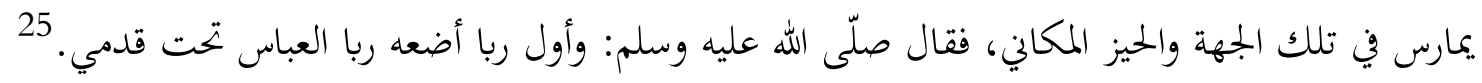

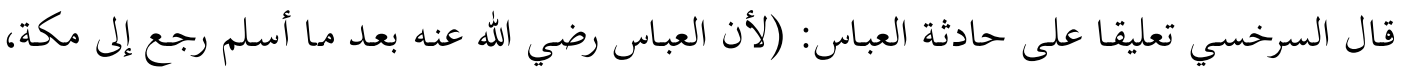

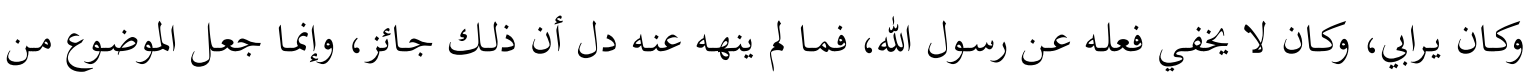

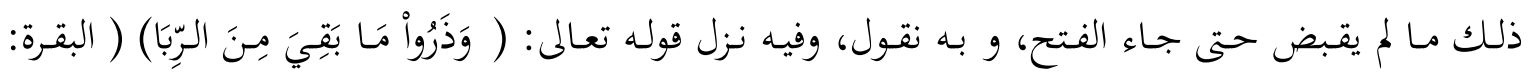

$$
24 \text { ابن عاشور. التحرير والتنوير، مصدر سابق، ج3، ص134. }
$$

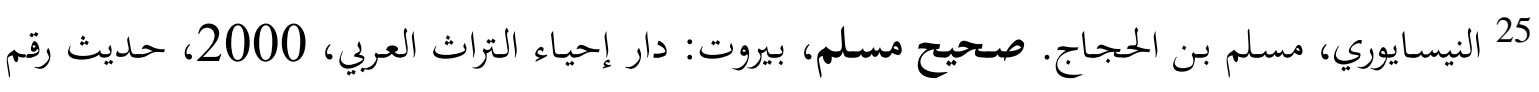




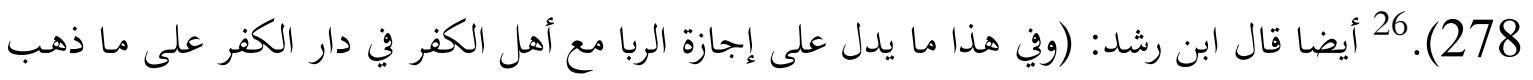

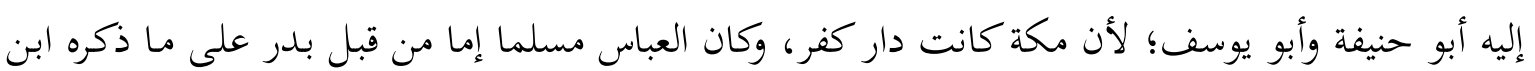
إسحاق، أو من قبل فتح خيبر إن لم يصح ما ذكره ابن إسحاق.

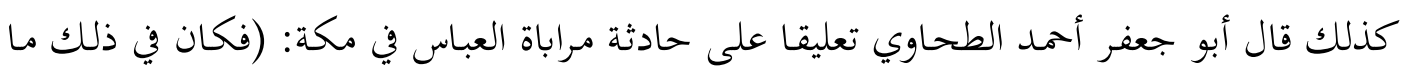

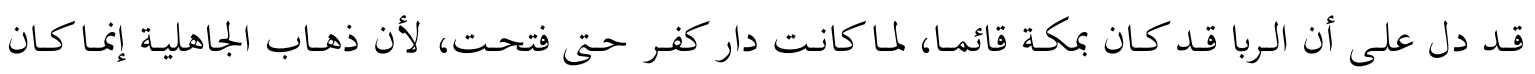

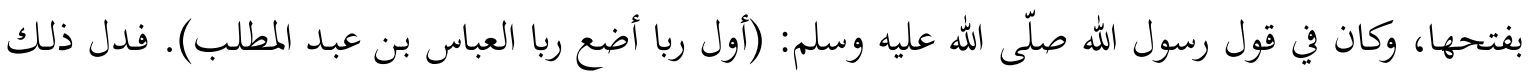

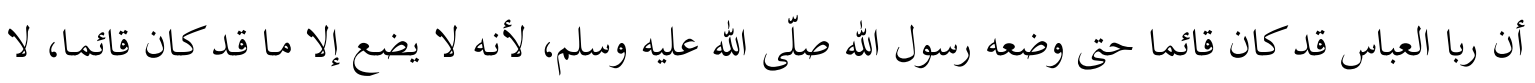

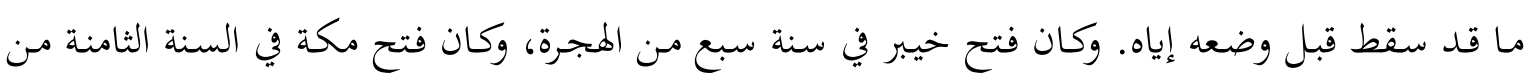

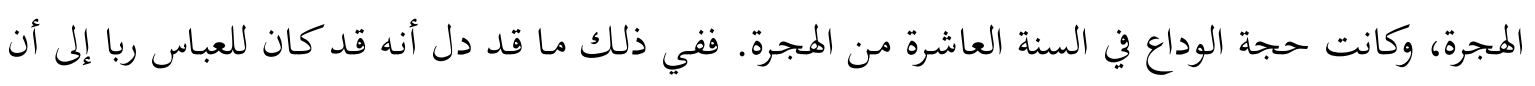

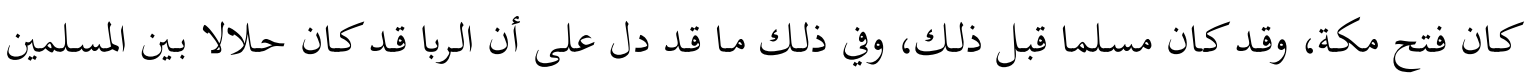

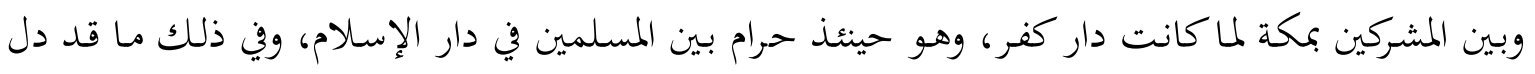
على إباحة الربا بين المسلمين وبين أهل الكفر في دار الكفر كما يقوله أبو حنيفة والثوري).

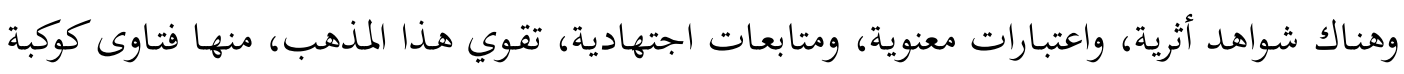

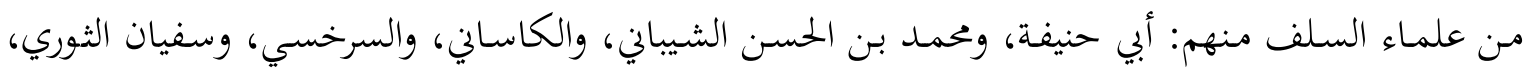

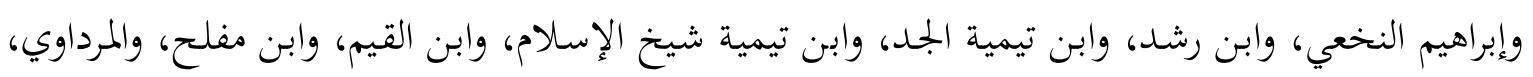

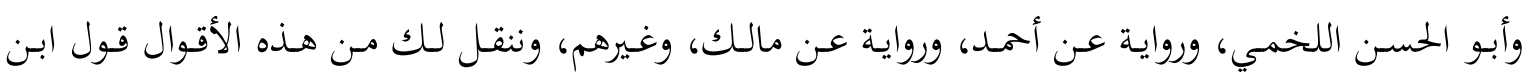
تيمية. 29

لا يخفى على أحد مدى تأثير كلام شيخ الإسلام ابن تيمية على الدعوة الإسلامية المعاصرة، فهو

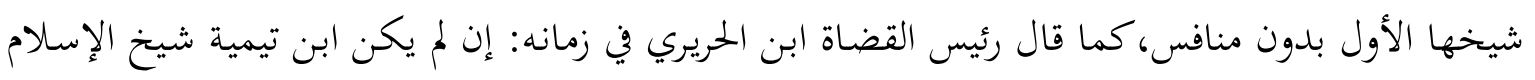
فمن هو ؟! ومن هذا المنطلق جعلت لكلامه هذه الخصوصية، فأفردت له ولابن القيم هذه المساحة.

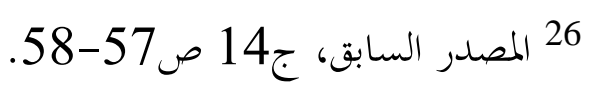

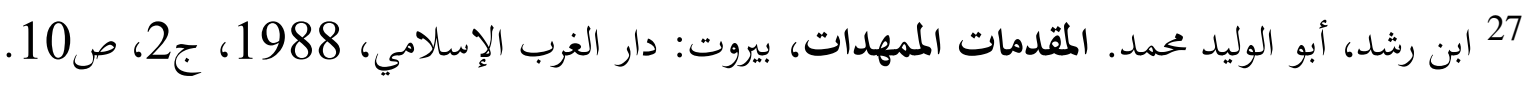

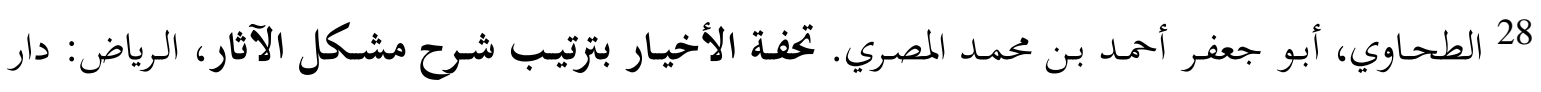

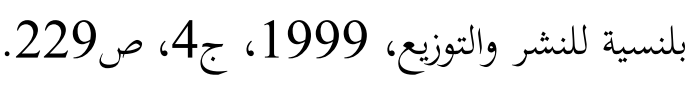
29 ابن قاسم، حممد بن عبدالرمن. المستدرك على مجموع فتاوى شيخ الإسلام ابن تيمية، الرياض: دار القاسم، ج4، ص129 صلئ. 
فقد ثبت عن هذا الإمام الجليل قوله بعدم حرمة الربا بين مسلم وغيره في غير دار الإسلام، كما ورد

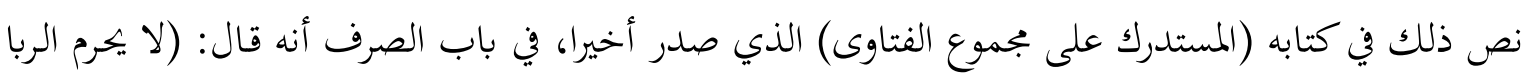

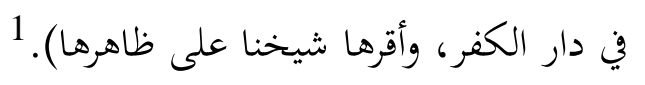

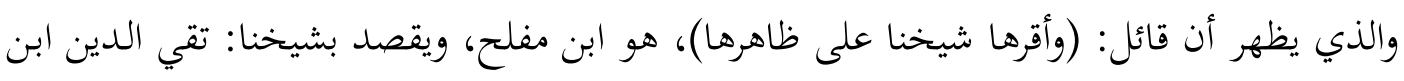

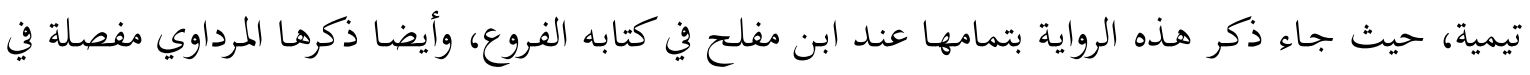

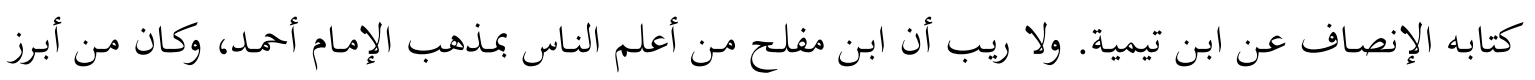

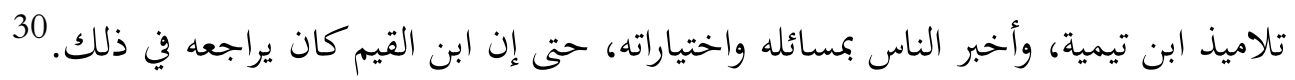

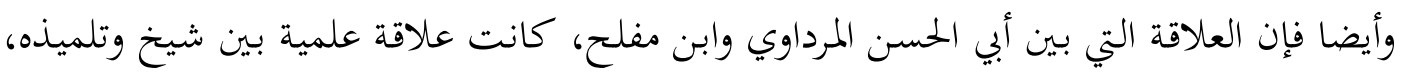

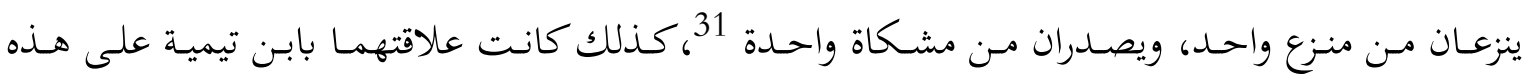

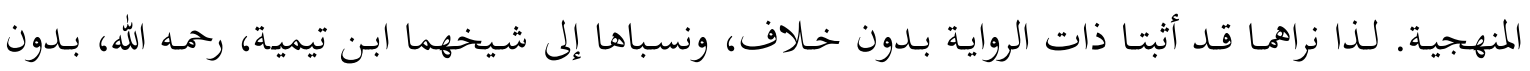

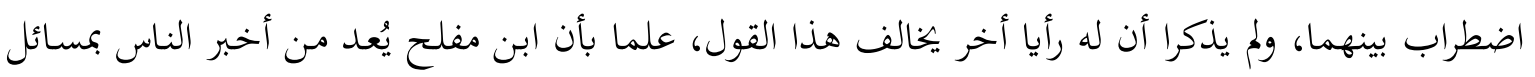

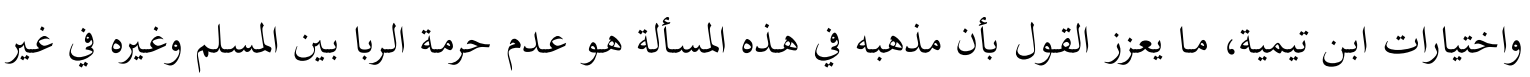

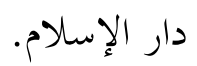

وهذا نص ابن مفلح يؤكد مـا قلته، فقد قال في فروعه: (وفي المستوعب، والمحرر 32: إلا بين مسلم

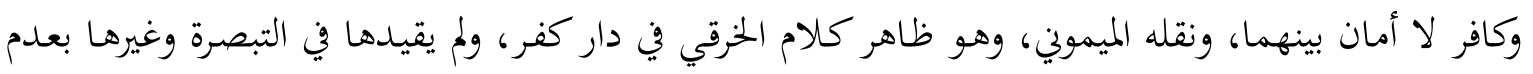

30 قال ابن القيم عنه: ما تحت قبة الفلك أعلم بمذهب الإمام أحمد من ابن مفلح، وحضر عند الشيخ تقي

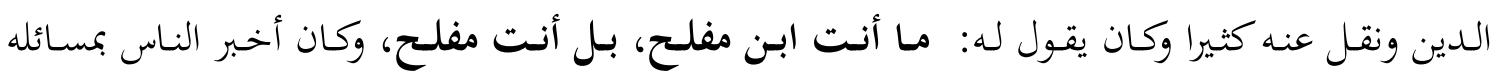

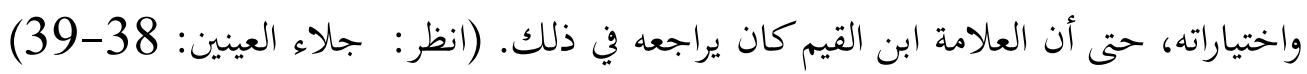

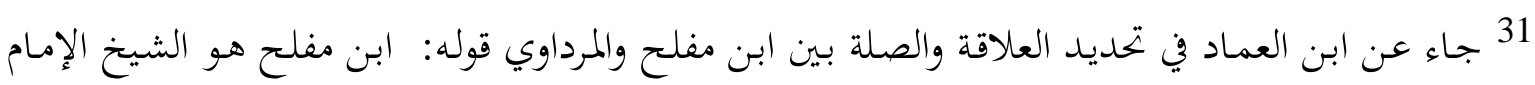

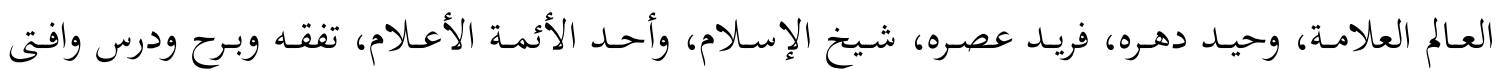

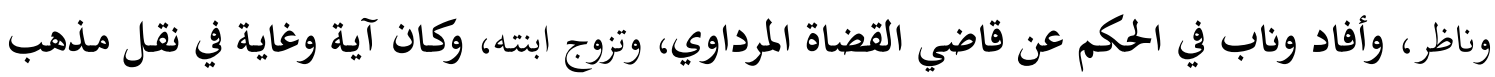

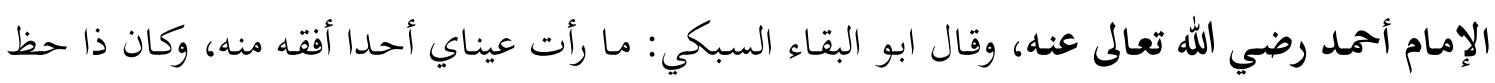

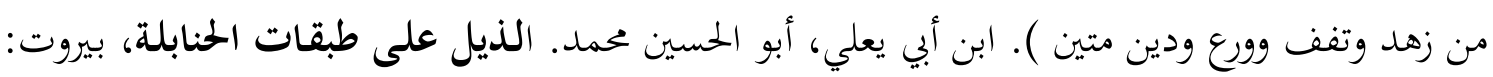

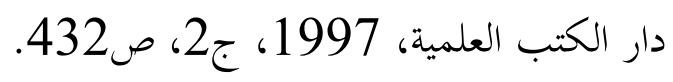

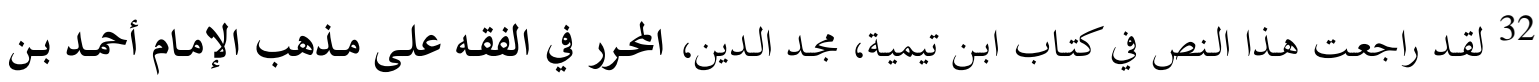

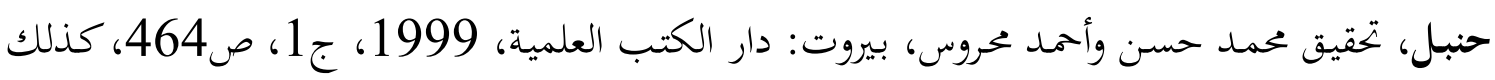


الأمان. وفي الموجز رواية: لا يحرم في دار الكفر، وأقرها شيخنا على ظاهرها، وعنه: لا ربا بينه وبين مكاتبه كعبده، فعلى المنع فلو زاد الأجل والدين جاز في احتمال. وهذه رواية أبي الحسن المرداوي مفصلة، تثبت ما قلته، قال وفي (الموجز روائة الماية): (لا يحرم الربا في دار

$$
\text { الكفر . وأقرها الشيخ تقي الدين (ابن تيمية) على ظاهرها) }
$$

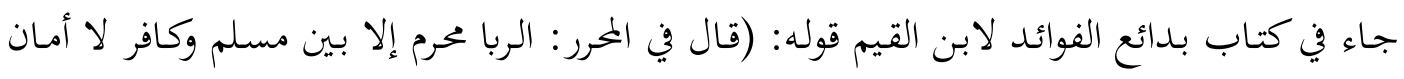

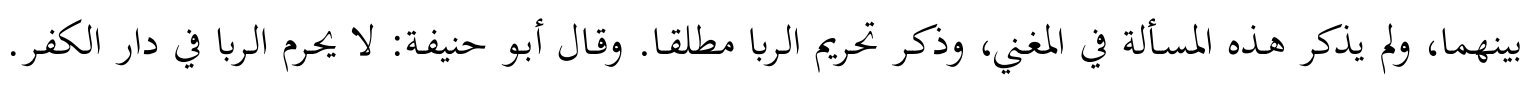

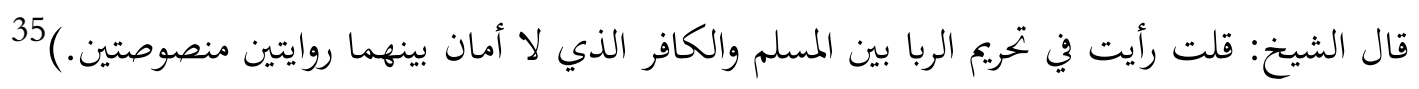

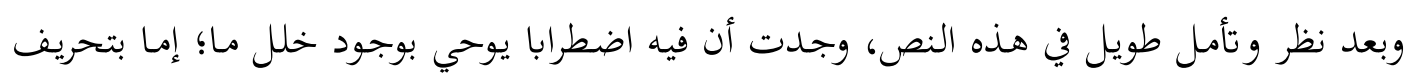

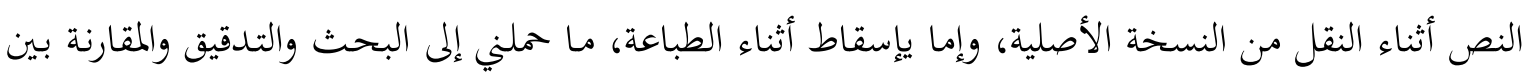

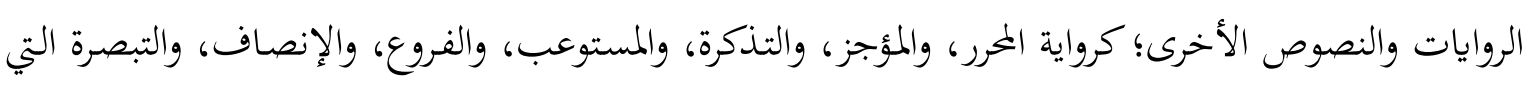
جاء ذكرها في كتاب الإنصاف والفروع وغيرهما.

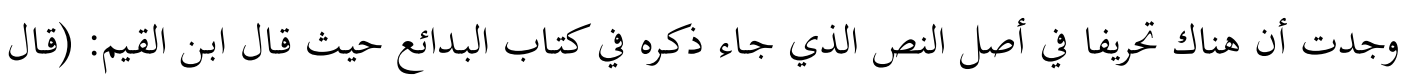

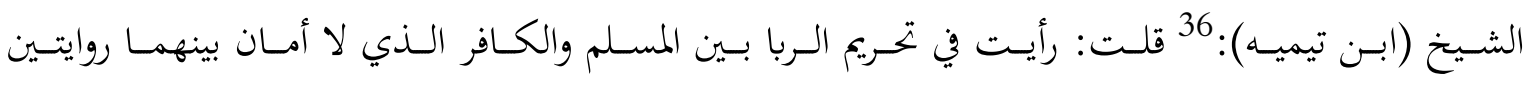
منصوصتين).

والصواب ينبغي أن يكون على هذه الصيغة: (رأيت في عدم تحريم الربا بين المسلم والكافر الذي لا أمان بينهما روايتين منصوصتين). ولا يخفى أن الروايتين التي أشار إليهما العلامة ابن القيم، هما: روايتا الموجز، والمحرر، التي جاء ذكرهما

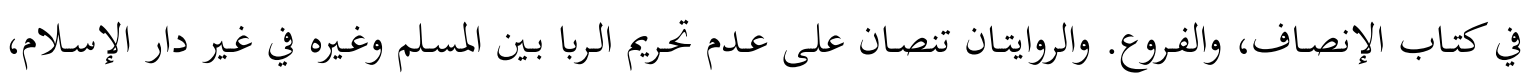

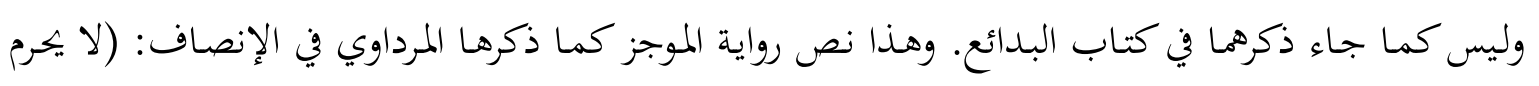

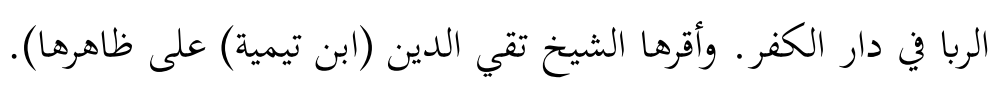

كتاب الحنبلي، ابن مفلح. المبدع شرح المقنع، بيروت: دار الكتب العلمية، 1997، ج4، ص154،

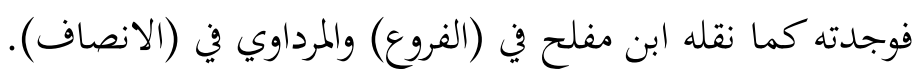

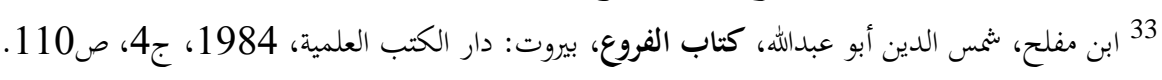

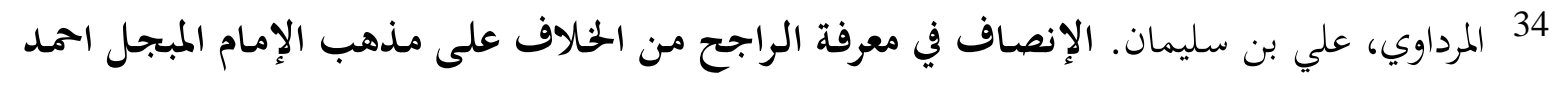

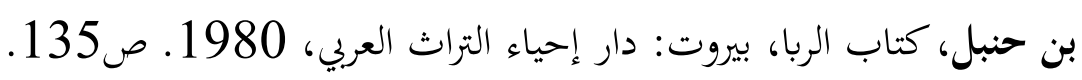

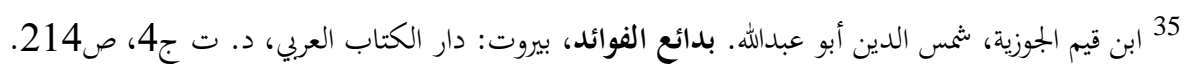
36 كلمة ابن تيمية من عندي وليس في أصل النص. 
وهذا نص رواية الحرر كما ذكرها ابن مفلح في الفروع: (إلا بين مسلم وكافر لا أمان بينهما). وكما

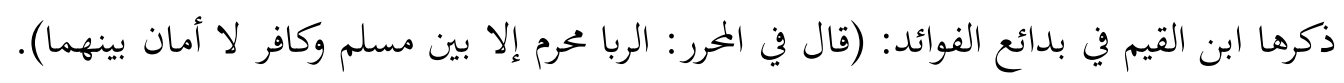

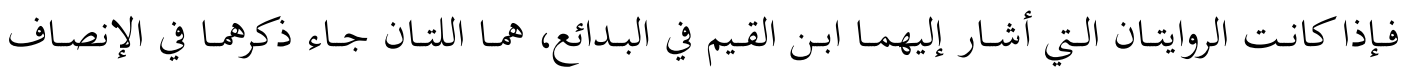

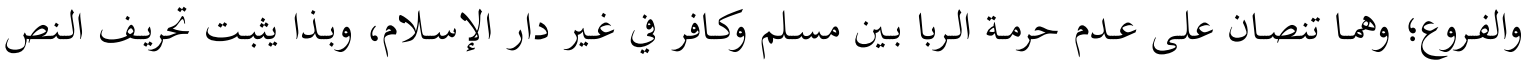

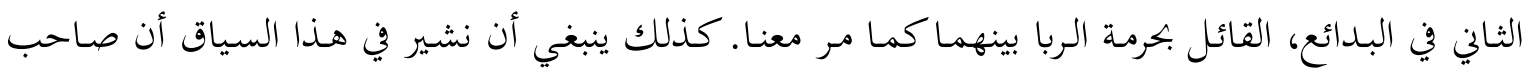

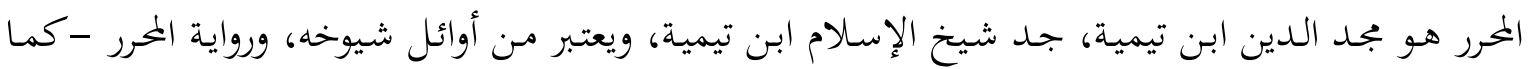

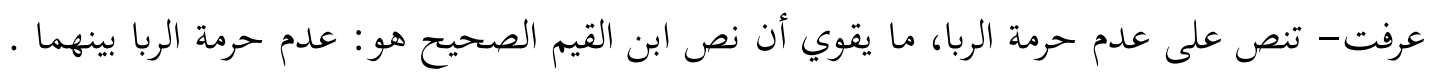

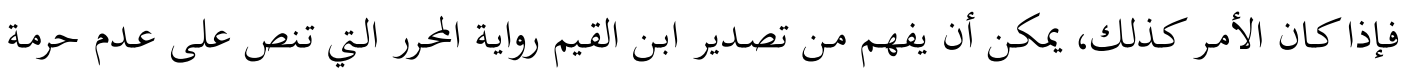
الربا بينهما، أها تشير إلى ترجيحه لها، لما علم عند أهل العلم من أن التصدير يؤذن بالتشهير، ثم بعد ذلك الك الته

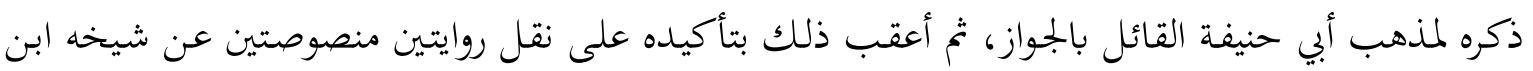

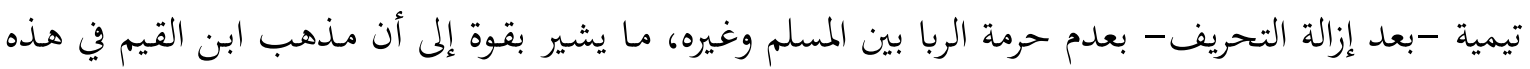

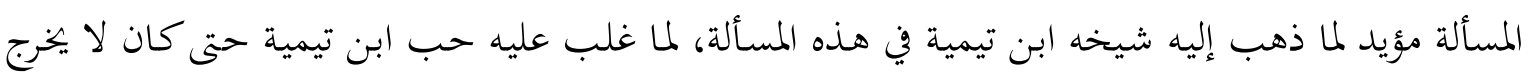
عن شيء من أقواله، بل ينتصر له في الغالب الأعم، والله أعلم.

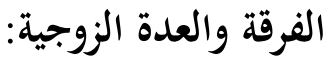

الفرقة بضم الفاء وسكون المهملة ضد الاجتماع، أي المباينة، وهي إذا كان الزوجان في دار الإسلام،

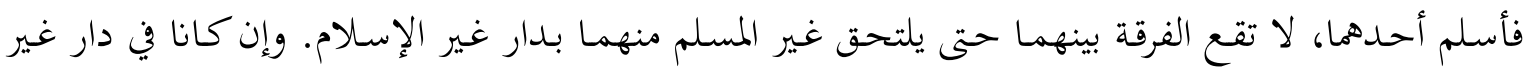

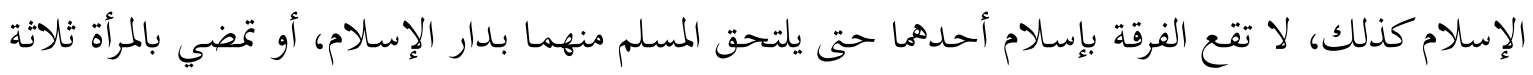

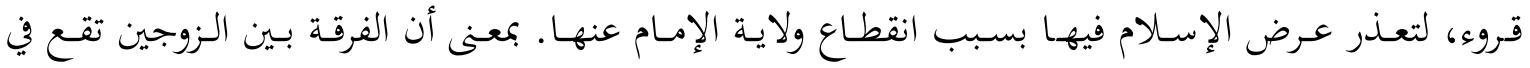

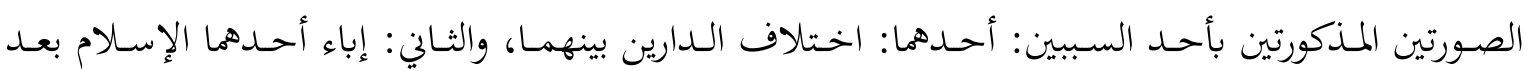

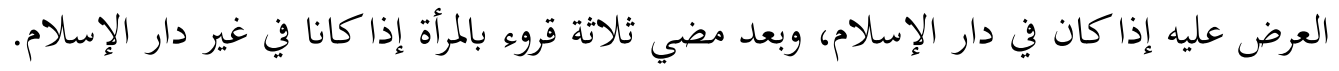

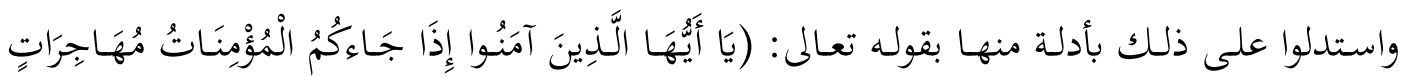

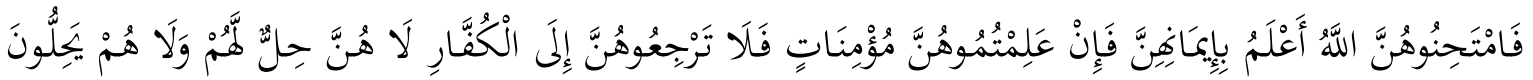

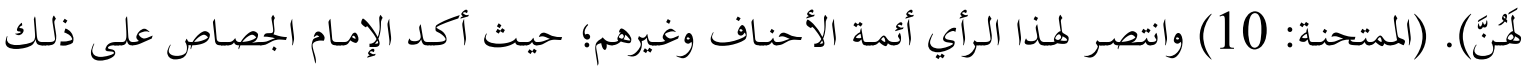

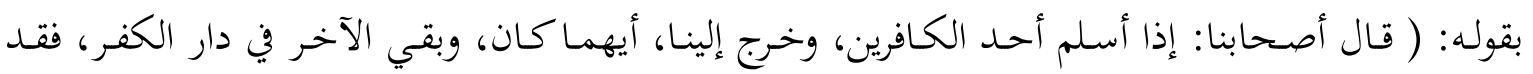
وقعت الفرقة باختلاف الدارين.)

(37 الجصاص، أبو بكر أمد. أحكام القرآن، بيروت: دار إحياء التراث، ج3، ص438. 


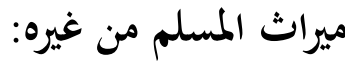

لقد أجمع العلماء على أن الكافر لا يرث المسلم في دار الإسلام، وذهبت طائفة إلى توريث المسلم

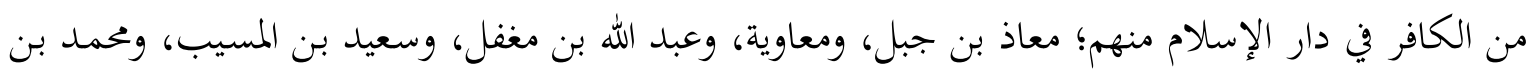
الحنفية، ومسروق، ويهيى بن يعمر، وهو اختيار شيخ الإسلام ابن تيمية وابن القيم رحمهما الله تعالى. ولكن أهل هذا الإجماع اعتبروا عند تطبيقه على حالات استثنائية يجب مراعاتها وأخذها في الاعتبار منها على سبيل المثال؛ اعتبروا اختلاف الدارين. حيث اعتبروه مؤثرا في إنزال الحلكم على مناطه سواء في حالة ميراث المسلم الأصلي مـن المسلم الجلديد، أو بين المسلم والكافر، وهـذا مـا قرره صـدر الإسـلام البزدوي، 38 والعتابي، 39 وغيرها من الأئمة، فقال العتابي: (المسلم الذي أسلم ولم يهاجر إلينا لا يرث من المسلم الأصلي في دارنا، ولا المسلم الأصلي من المسلم الذي لم يهاجر، سواء كان في دار الكفر مستأمنا أو لم يكن. وعلل صدر الإسلام البزدوي ذلك قائلا: (لأنه من أهل دار الإسلام، فاختلف بهما الداران، وهو

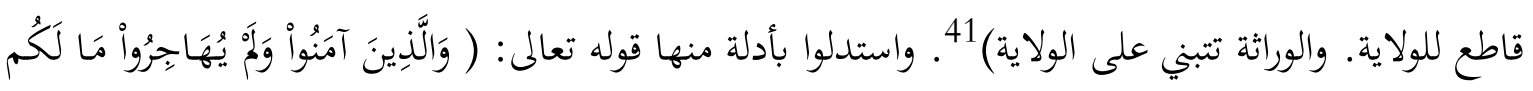

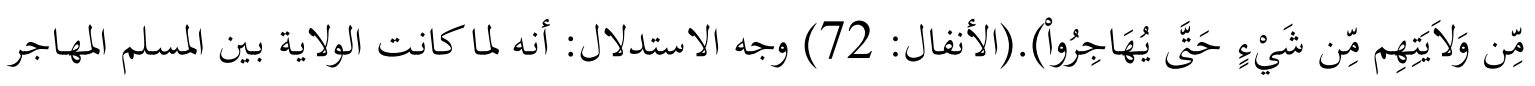
وبين المسلم الذي لم يهاجر منتفية، كان الميراث منتفيا، لأن الميراث مبني على الولاية.

\section{العقوبات الحدية:}

لا يخفى أن أحكام الشريعة جملة وتفصيلا واجبة التطبيق على المسلمين حكاما ومحكومين في ديار

الإسلام للقدرة والاستطاعة، أما في ديار غير المسلمين حيث لا سيادة للأمراء ولا سلطان على تلك الأراضي مما يجعل القدرة والاستطاعة منتفية عنهم جملة، فلا بحب -هم وليس عليهم- إقامة العقوبات الحدية، والنظم الإسلامية (السياسية، والقانونية،والقضائية، والاقتصادية) على أفراد أو جالية مسلمة خاضعة لسيادة دساتير وقوانين دول أخرى ليس لهم ولاية عليها؛ بل تعد هذه الجالية من الناحية القانونية في عداد رعايا تلك الدول غير الإسلامية.

قال ابـن تيميـة: (خاطب الله المؤمنين بالحـدود والحقـوق خطـابا مطلقا، كقوله: (والسـارق والسـارقة

فاقطعوا أيديهما) وقوله: (الزانية والزاني فاجلدوا)، وقوله: (والذين يرمون المحصنات ثم لم يأتوا بأربعة شههاء فاجلدوهم) وكذلك قوله: (ولا تقبلوا لمم شهادة أبدا) ؛ لكن قد علم أن المخاطب بالفعل لابد أن يكون قادرا

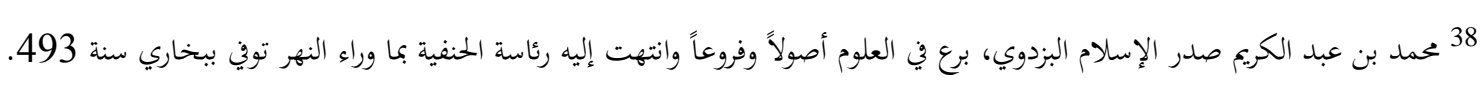

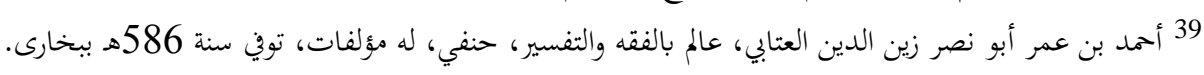

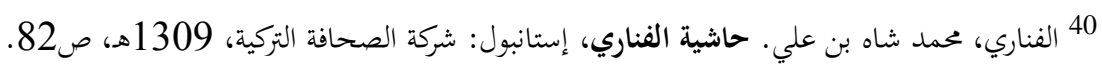
41 
عليه، والعاجزون لا يجب عليهم، وقد علم أن هذا فرض على الكفاية، وهو مثل الجهاد؛ بل هو نوع من

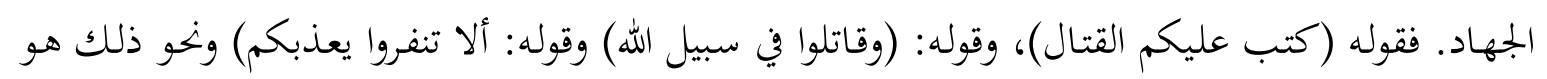

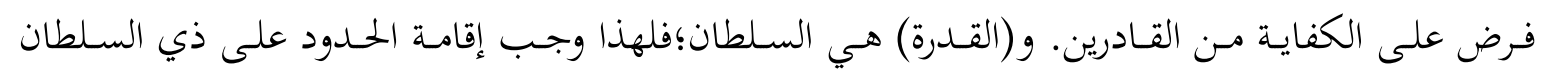
ونوابه.

ولعل في تبويب الفقهاء بابا مستقلا تحت عنوان: لا تقطع الأيدي في الغزو، ولا تقام الحدود في

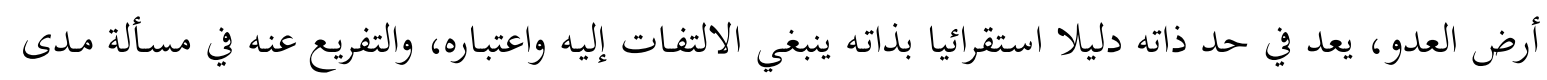

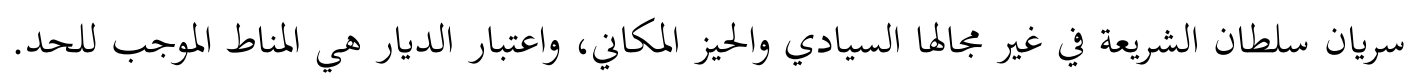

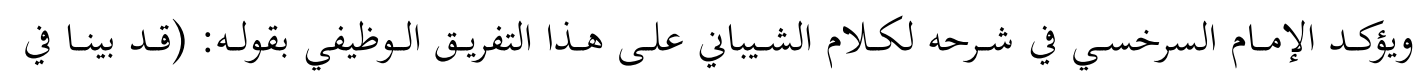

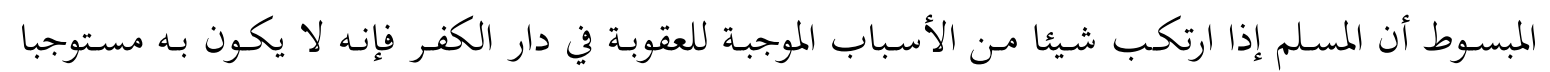

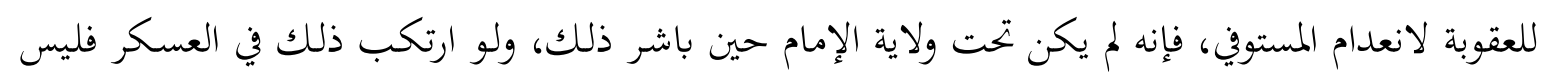

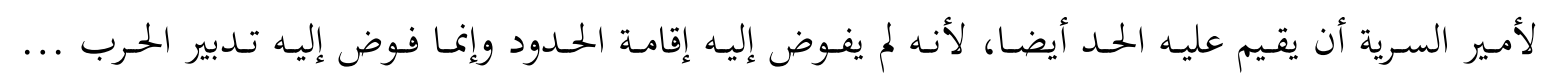

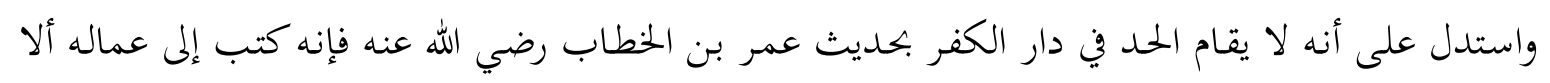
يجلدن أمير الجيش ولا سرية أحدا حتى يخرج إلى الدرب قافلا؛ لئلا يلحقه حمية الشيطان فيلتحق بار بالكفار.

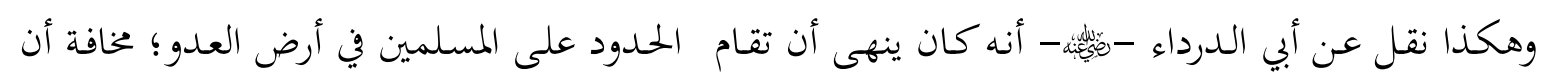

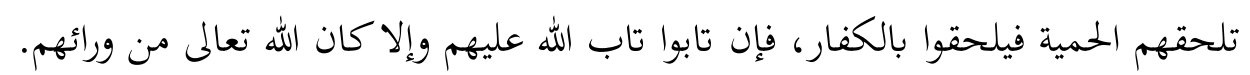

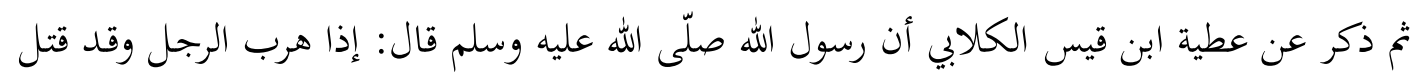

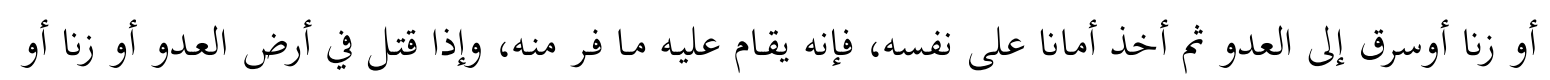

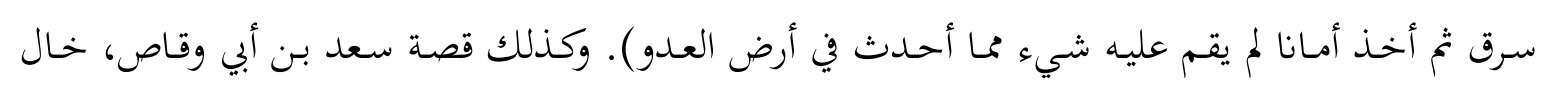

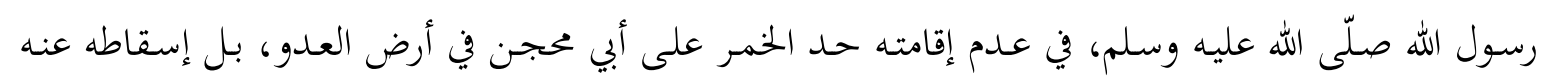
جملة بعد بلائه الحسن في المعركة.

الخاتمة

لا يخفى أن تحرير فلسفة اختلاف الدارين وأثرها على أحكام المعاملات، والسياسات العامة، على

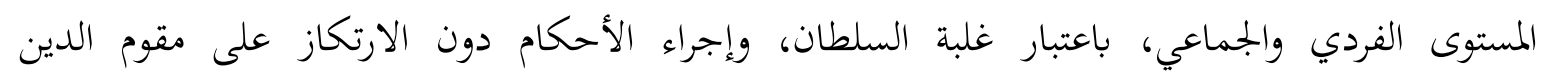

42 ابن تيمية. ججموع الفتاوى، ج34، ص175، 173 43 السرخسي. المبسوط، مصدر سابق، ج1، ص220. 
واختلافات الديانات، يعطي المسلم المعاصر المقيم في الغرب مجالات متعددة، ومساحات واسعة، ومسالك

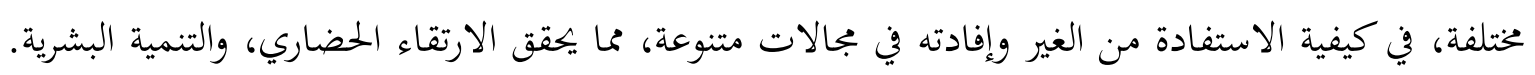

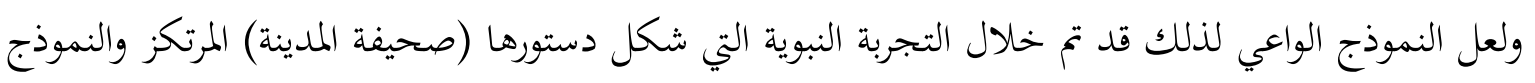

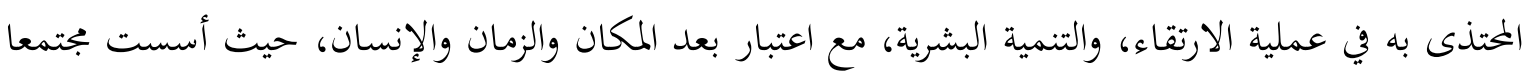

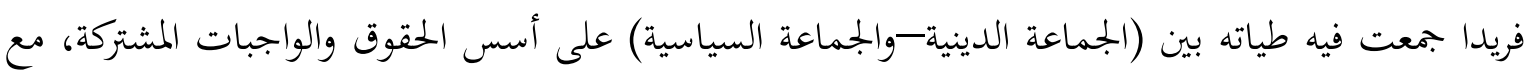

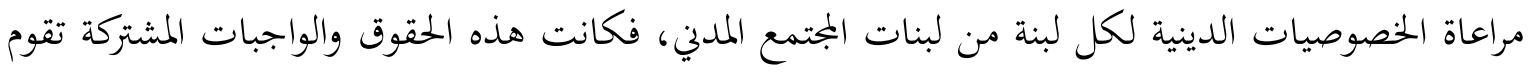

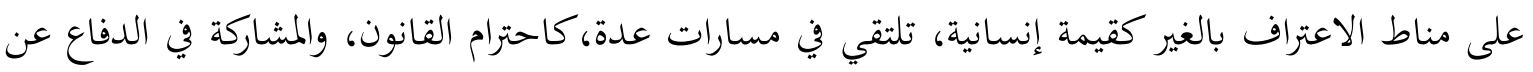

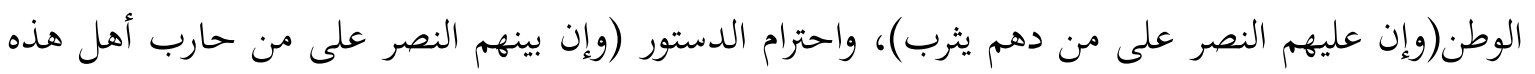

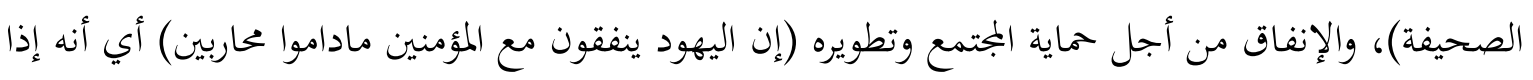

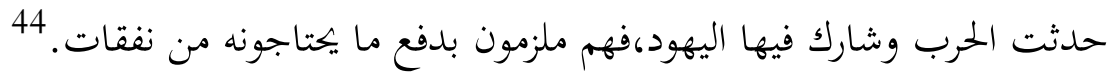

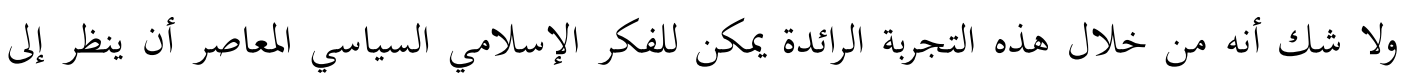

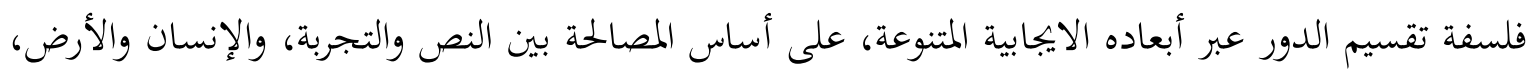

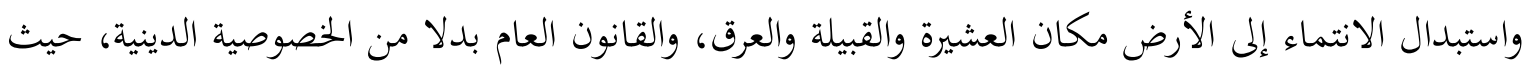

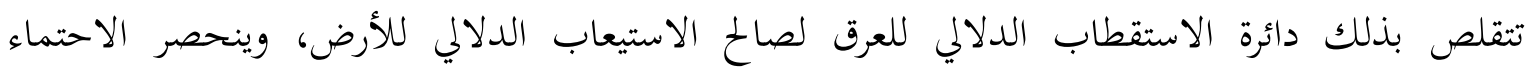

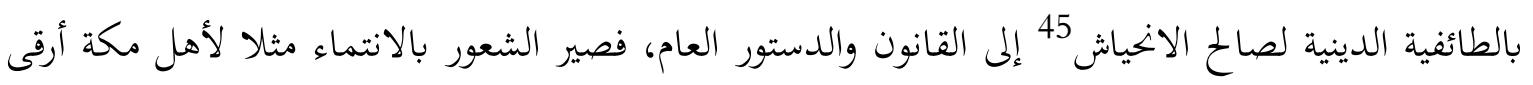

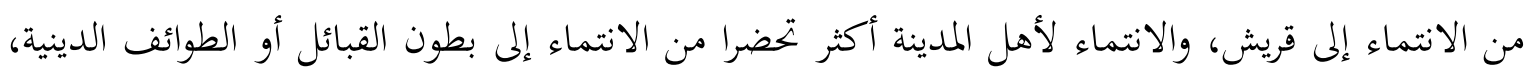

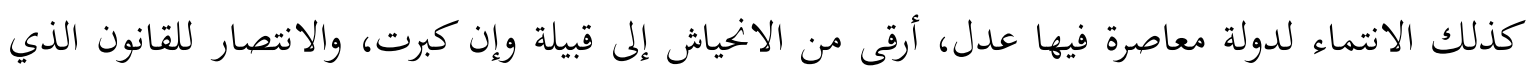

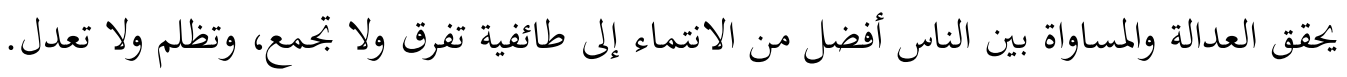

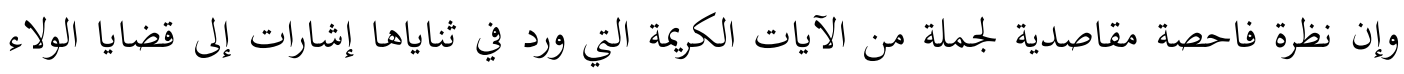

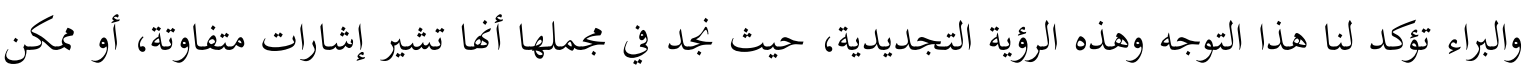

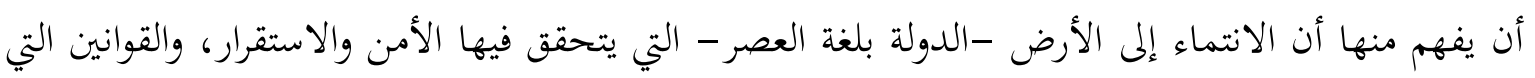

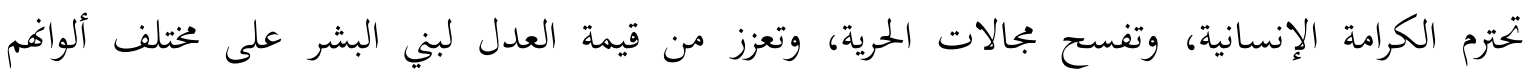

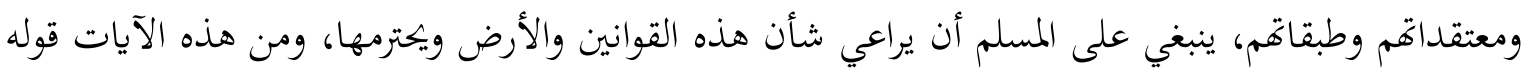

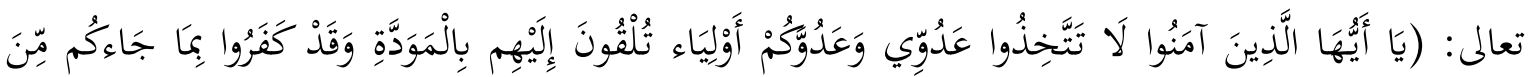

44 آبادي، محمد حميد الله. مجموعة الوثائق السياسية في العهد النبوي والحلافة الراشدة، القاهرة: مكتبة الثقافة الدينة، د. ت، ص5 ص-6. 45 هذا المصطلح استعمله الشاطبي في الاعتصام. 


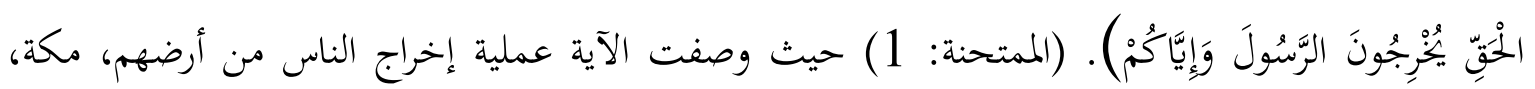

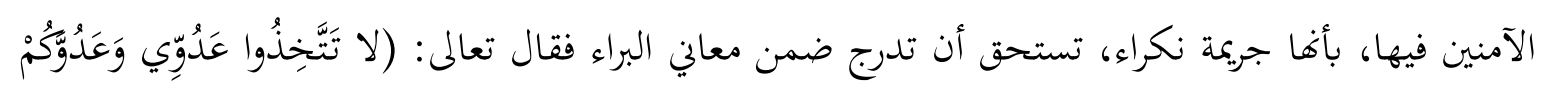

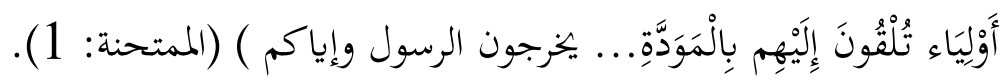

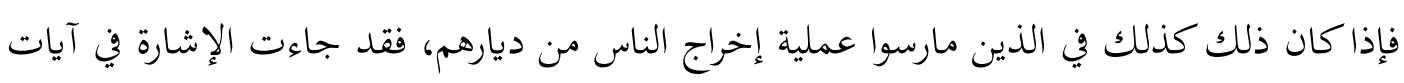

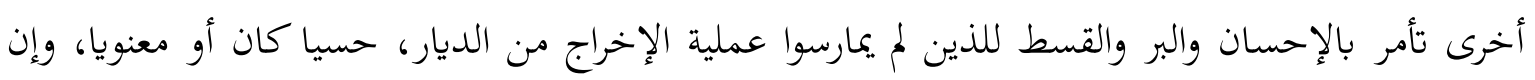

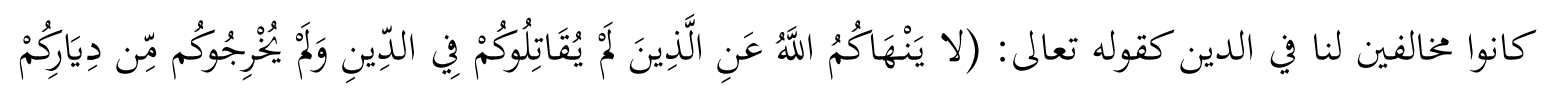

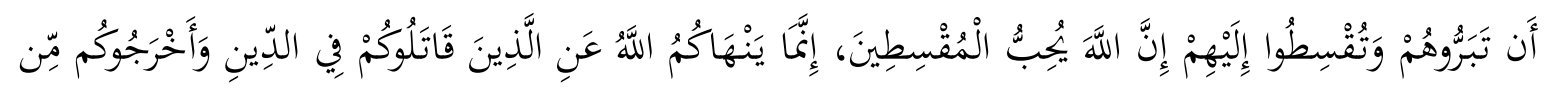

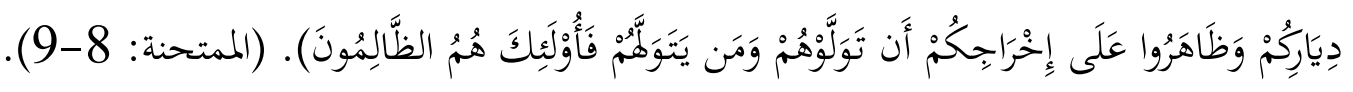

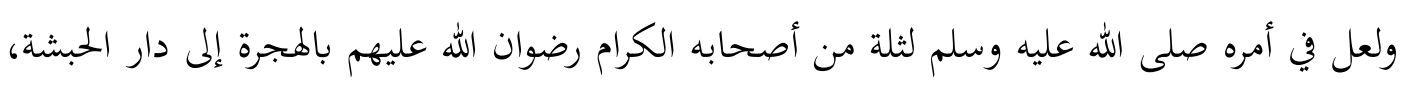

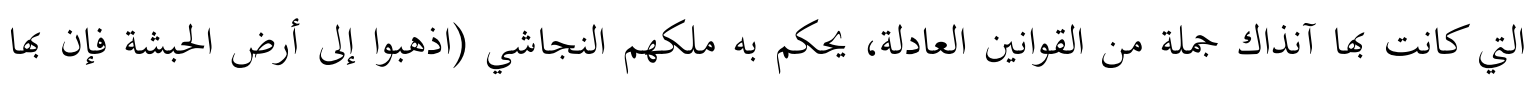

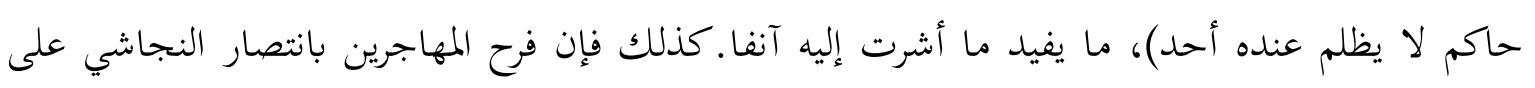

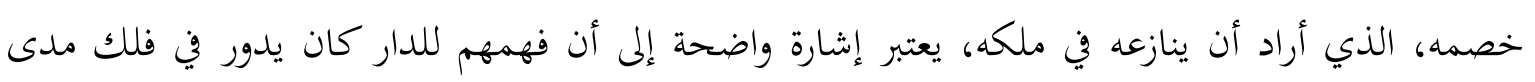

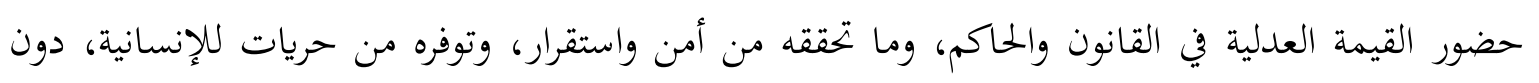

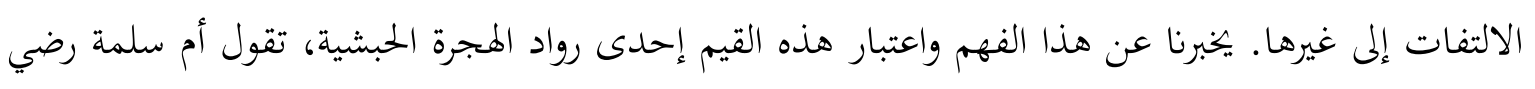

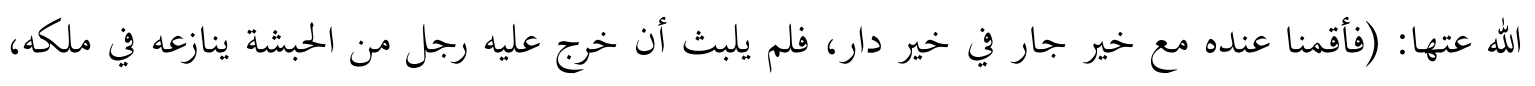

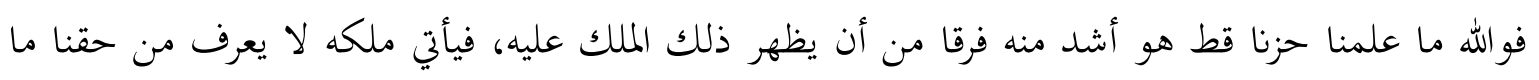

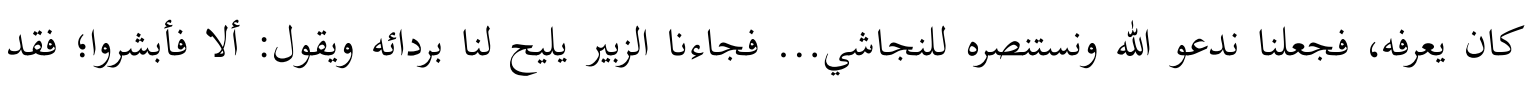

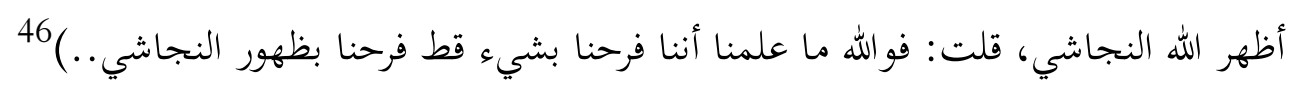

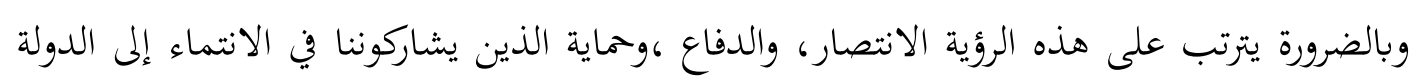

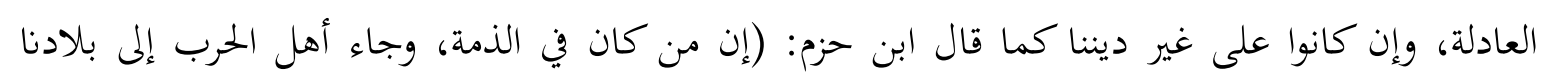

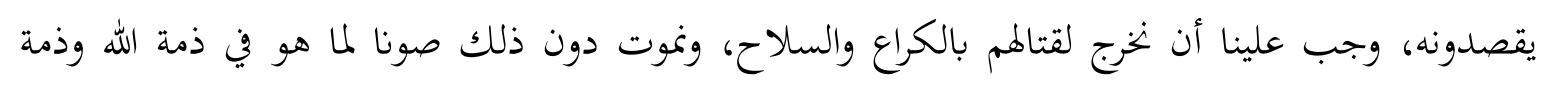

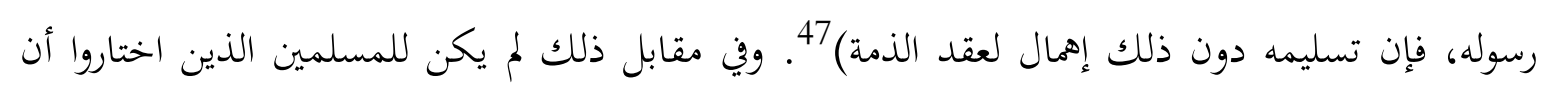

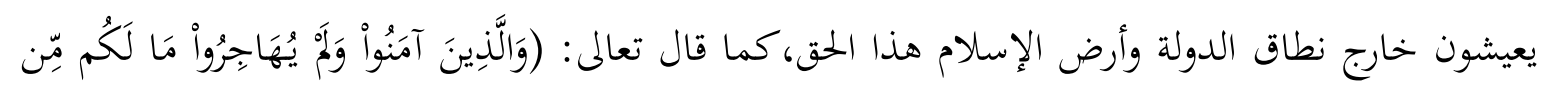

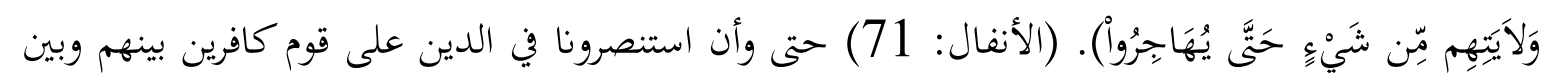

46 ابن كثير، عماد الدين أبو الفداء إسماعيل. البداية والنهاية، القاهرة: دار الحديث، 1992، ج3، ص123. 47 ابن حزم، الخلى، مصدر سابق. 


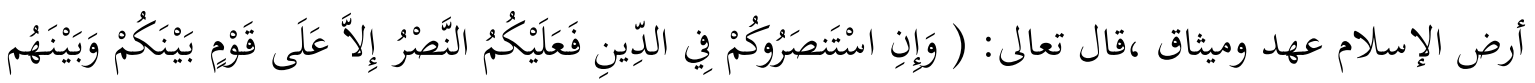

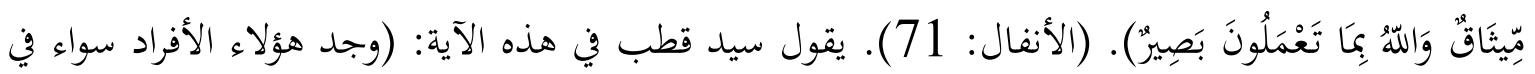

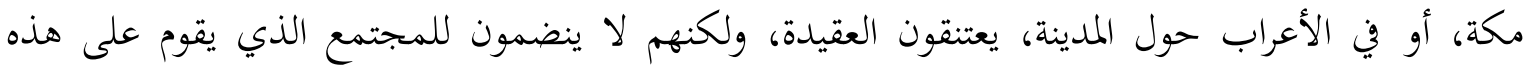

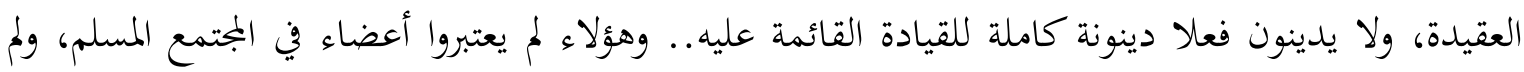

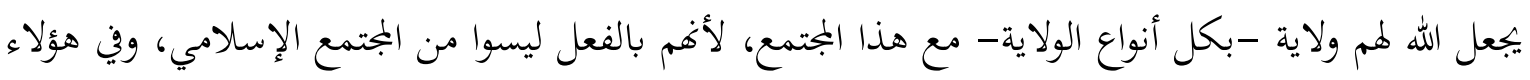

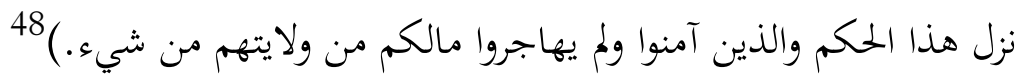

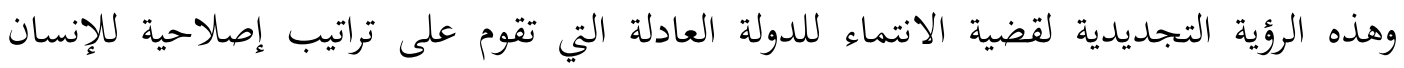

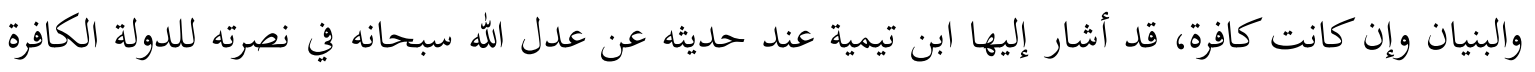

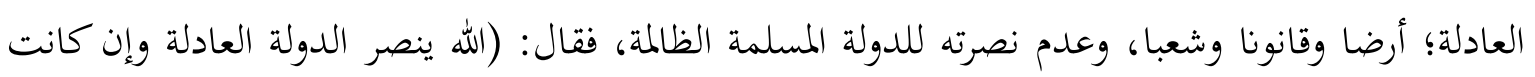

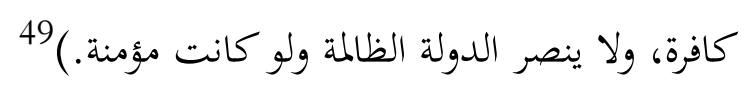

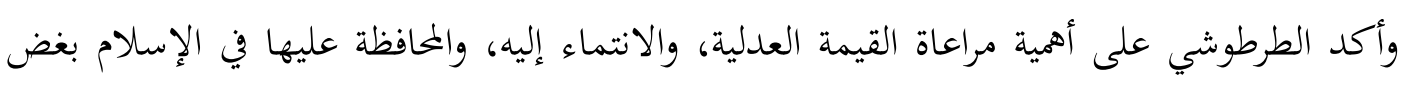

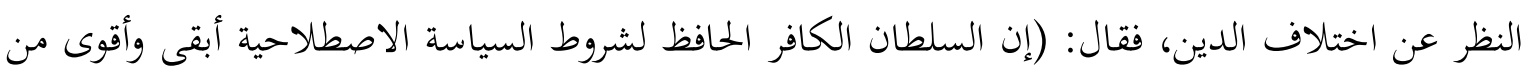

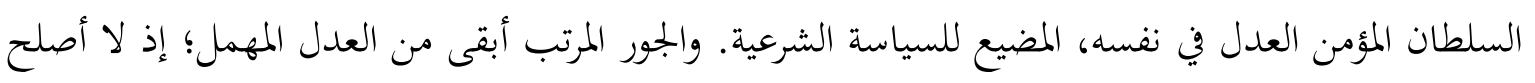

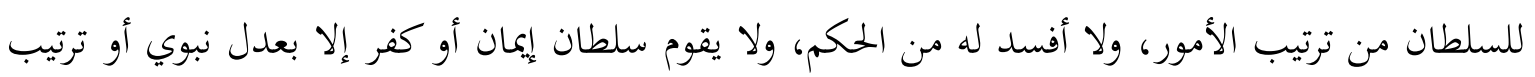
اصطلاحي.) وبجذه الرؤية لمصطلح اختلاف الدارين نكون قد أضفنا إليه مفاهيم إيجابية في إطار التعاون والتعايش،

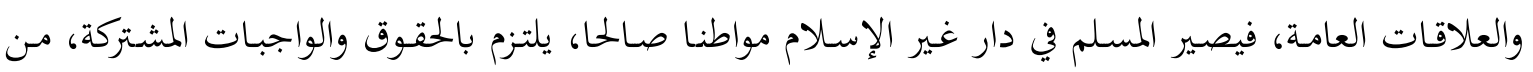

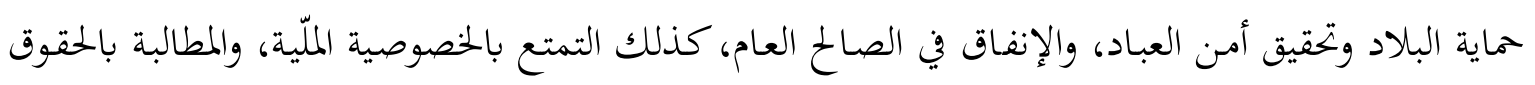

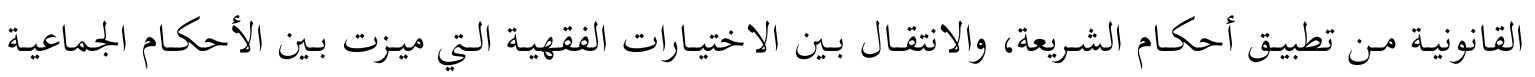

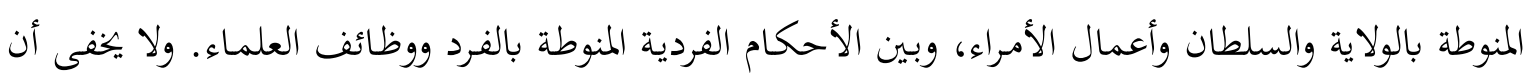

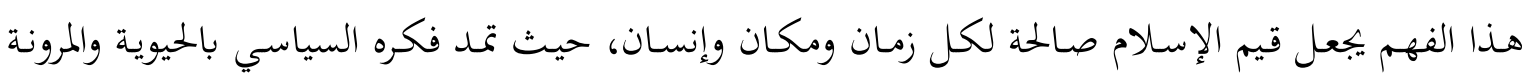
والقدرة على توصيف الواقع، وتكيف الأحكام والتكيف معها استضعافا واستخلافا.

$$
48 \text { قطب، سيد. في ظلال القرآن، مصدر سابق، ج3، ص1559. }
$$

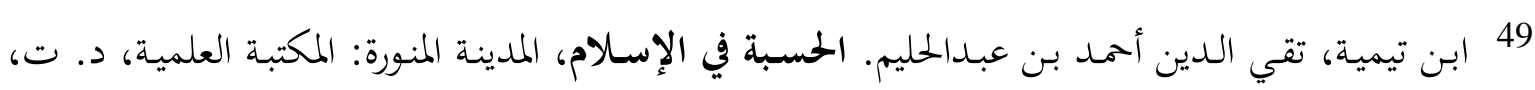
صن 50

50 الطرطوشي، محمد بن الوليد. سراج الملوك، القاهرة: الدار المصرية اللبناني، 1994: ج1، ص54. 